\title{
CREDIT RATING AGENCIES, THE SOVEREIGN DEBT CRISIS AND COMPETITION LAW
}

I. INTRODUCTION

II. OVERVIEW OF THE CREDIT RATING INDUSTRY

III. THE CASE FOR ANTITRUST INTERVENTION

A. The Prima Facie Features of Significant Market Power

1. Significant Market Power, Information Goods and Reputational Damage

2. The Structural Features of SMP

3. The Behavioral Performance of SMP

4. Alternative theories

5. Conclusions

B. Antitrust Intervention v. Sector Specific Regulation?

1. Background

2. Intrinsic Limits of Alternative Regulatory Remedies

a) Effectiveness Issues

b) Process Issues

3. The Advantages of Antitrust Intervention

IV. ANTITRUST INTERVENTION SCENARIOS

A. Theoretical and Factual Background

B. Collusion

C. Abuse of Dominance

1. Market definition

2. Dominance

2.1. Single firm Dominance

2.2. Collective Dominance

3. Abuse

D. Competition Advocacy

V. REMEDIES

A. Background

B. Remedies creating or assisting "competitive forces" external to the Oligopoly

C. Remedies seeking to reduce Risks of Ratings Errors

D. Remedies seeking to eliminate Coordination within the Oligopoly

VI. CONCLUSION 


\title{
CREDIT RATING AGENCIES, THE SOVEREIGN DEBT CRISIS AND COMPETITION LAW
}

\begin{abstract}
Nicolas PETIT ${ }^{*}$
Abstract (EN): this paper demonstrates that there are both theoretical and practical reasons to scrutinize, and possibly regulate, the conduct of the credit rating agencies under European Union competition law.
\end{abstract}

Résumé (FR): cet article démontre, dans une perspective à la fois théorique et pragmatique, que les pratiques des agences de notation peuvent faire l'objet d'un contrôle, et le cas échéant, être régulées, sur le fondement du droit européen de la concurrence.

\section{Introduction}

The "Big Three" Credit Rating Agencies ("CRAs") rank highly on the "most wanted" list of policy leaders in the Western world. Moody's Investors Services (“Moody's”), Standard \& Poor's ("S\&P") and Fitch Ratings ("Fitch") are blamed for mistakenly downgrading sovereign States in the European Union ("EU”) and the United States ("US"), and in turn for plunging financial markets into a state of profound distress. With swelling interest rates, downgraded States have been brought even closer to the brink of default, as if CRAs' pessimistic predictions (some talk of "prophecies") were self-fulfilling. ${ }^{1}$ Calls for regulatory intervention against CRAs have thus escalated, with proposals as diverse as the creation of government-sponsored CRAs, ${ }^{2}$ the dismantling of the CRA oligopoly, ${ }^{3}$ or tougher controls on sovereign ratings. ${ }^{4}$ In addition, it has been reported that a number of private investors have been exploring opportunities to enter this market. ${ }^{5}$

\footnotetext{
* Professor, University of Liège (ULg), Belgium. Director of the Global Competition Law Centre (GCLC) College of Europe. Director of the Brussels School of Competition (BSC). Nicolas.petit@ulg.ac.be. The author is indebted to his assistant Norman Neyrinck, who provided great research assistance in the early preparation of this paper. Very many thanks also to David Henry, barrister, who thoroughly reviewed the present document and made useful comments. Unless stated otherwise, all views, opinions, interpretations and possible errors are mine, and shall not be attributed to the people who commented on this paper.

${ }^{1}$ J. de Haan and F. Amtenbrink, Credit Rating Agencies, De Nederlandsche Bank Working Paper No. 278, January 2011, p. 6. who explain the phenomenon as follows: "downgrade to below the investment-grade threshold often triggers immediate liquidation, leading to herd behaviour. This kind of behaviour may increase market volatility and may even cause a self-sustaining downward spiral of asset prices with potential negative effects for financial stability".

${ }^{2}$ Interview of M. Barnier, La tribune, Jeudi 7 Juillet 2011, available at http://ec.europa.eu/commission_20102014/barnier/docs/interviews/20110707_latribune_fr.pdf

${ }^{3}$ Interview of V. Reding, Härte gegen Griechen aus Sorge um Italien, Die Welt, 11.07.2011, available at http://www.welt.de/print/die_welt/wirtschaft/article13479660/Haerte-gegen-Griechen-aus-Sorge-um-Italien.html

${ }^{4}$ For an overview, see J. Rega, “The Rating Game”, ${ }^{m}$ Lex Magazine, July September 2011, pp.34-36.

5 Deutsche Welle, "New European ratings agency slated to open next year", 19.07.2011, available at http://www.dw-world.de/dw/article/0,15250217,00.html
} 
Interestingly, most proposals have focused on the adoption of a dedicated regulatory framework to address the issue. In contrast, only a few of them envision remedial action pursuant to the competition rules. ${ }^{6}$ This is surprising, given that the market for rating services exhibits a range of structural - oligopolistic structure - and behavioral - parallel conduct features prone to antitrust scrutiny. In addition, the toolbox of antitrust agencies comprises flexible remedies which could be instrumental in regulating the CRA oligopoly.

Against this background, the present paper seeks to explore the possibilities for remedial intervention against the CRAs under the competition rules. To this end, it is divided in six parts. Following this introduction, Part II provides an overview of the credit rating industry. Part III demonstrates that there is a possible economic case for antitrust intervention against the CRAs. Part IV examines the doctrines of competition law that could be applied against CRAs. Part V reviews possible remedies. Part VI provides a conclusion. The below analysis is conducted on the basis of EU competition law. Subject to national legal idiosyncrasies, it applies mutatis mutandis to other competition law regimes.

\section{Overview of the Credit rating industry}

Definition - CRAs issue ratings to convey information on the ability of a debt issuer to repay its debt. ${ }^{7}$ Credit ratings help investors overcome the information asymmetry that exists between them and debt issuers. With the publication of specialized, independent and prospective assessments on debt issuers' creditworthiness, CRAs reduce information costs, increase the pool of potential lenders/borrowers and promote liquidity on markets. ${ }^{8}$

Market participants - The credit rating industry is a global business controlled by only a few players. ${ }^{9}$ Whilst one can enumerate approximately 74 CRAs throughout the world, the three major CRAs, namely Moody's, S\&P and Fitch, account for $94 \%$ of the global market. ${ }^{10}$ Moody's and S\&P each hold a 40\% market share. Fitch, which became the third important

\footnotetext{
${ }^{6}$ D. Nelson, "EC sees no abuse in CRA actions, but monitors behaviour "every day"”, 12.07.2011, M-Lex. See however, Huw Jones, Lawmakers urge competition probe of raters, Reuters, 21.07.2011, http://uk.reuters.com/article/2011/07/20/uk-raters-idUKTRE76J7R420110720 (about a call from the United Kingdom's House of Lords' EU economic and financial affairs committee).

${ }^{7}$ According to the International Monetary Fund (IMF): "A credit rating measures the relative risk that an entity or transaction will fail to meet its financial commitments, such as interest payments and repayment of principal, on a timely basis". See IMF, The uses and abuses of sovereign credit ratings, IMF Global Financial Stability Report, October 2010, p. 88.

${ }^{8}$ Ibidem, p. 86.

9 For a historical account of the evolution of the industry, see B. Cohen and B. G. Carruthers, "Credit, Classification and Cognition: Credit Raters in 19th-Century America", October 20, 2009, available at http://ssrn.com/abstract=1525626.

${ }^{10}$ For a full list, see IMF, Annex 3.1., p.118.
} 
player in the early 2000s, is reported to control $15 \%$ of the market. ${ }^{11}$ Moody's and S\&P are US firms. ${ }^{12}$ Fitch is a majority-owned subsidiary of Fimalac, S.A., a French firm. ${ }^{13}$

Business model - Since the 1970s, most CRAs subscribe to the so-called "issuer pays" business model. Firms and governments that issue debt - or more precisely the banks that are commissioned to issue securities on their behalf - pay CRAs to rate their credit-worthiness. Ratings are subsequently disclosed to the public for free. In the past, the banks and the money market funds themselves carried out credit worthiness assessments. ${ }^{14}$ In a bid to cut costs, however, they progressively outsourced most, if not all, of their internal ratings activities to CRAs.

Credit rating grids typically distinguish between two general types of grade, namely "Investment grade" and "Non investment grade" (or "junk bonds"). Each CRA, however, uses a more accurate rating scale. A common feature to all of them is a reliance on a combination of alphanumerical characters to reflect the credit worthiness of debt issuers (see table below). Ratings are determined primarily using a 3-5 year time horizon - at least in case of S\&P

\begin{tabular}{|c|c|c|c|c|}
\hline \multicolumn{5}{|c|}{ CREDIT RATINGS' } \\
\hline & & MOODY'S & STANDARD \& POOR'S & $\mathrm{FITCH}$ \\
\hline \multirow{4}{*}{ 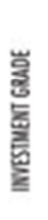 } & \multirow{4}{*}{ STRONGEST } & Aaa & AAA & AAA \\
\hline & & Aa & $A A$ & AA \\
\hline & & A & A & A \\
\hline & & Boo & BBB & BBB \\
\hline \multirow{6}{*}{ 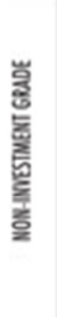 } & \multirow{6}{*}{$\prod_{\text {WEAKEST }}$} & $\mathrm{Ba}$ & BB & $B B$ \\
\hline & & B & 8 & B \\
\hline & & $\mathrm{Coa}$ & $\mathrm{CCC}$ & $\mathrm{CCC}$ \\
\hline & & $\mathrm{Ca}$ & $\mathrm{CC}$ & $\mathrm{CC}$ \\
\hline & & $c$ & C & $c$ \\
\hline & & $C$ & D & $D$ \\
\hline
\end{tabular}

Table 1 - Overview of the Credit Ratings Grids of the "Big Three" CRAs ${ }^{15}$

\footnotetext{
11 Hence, the expression the "Big Three". OECD, Competition and Credit Rating Agencies, DAF/COMP(2010)29, 5 October 2010, p. 7.

${ }^{12}$ Moody's is controlled by two US financial and investment companies, i.e. Berkshire Hathaway and Davis Selected Advisers. S\&P is a division of the publicly traded McGraw-Hill Companies, a group active in the education, media and publication businesses.

${ }^{13}$ J. Rega, "The Rating Game”, M-Lex Magazine, July September 2011, 34. Fimalac S.A. is active in financial markets, investments and real estate.

${ }^{14}$ Faith in ratings, Wall Street Journal, 23 September 2008.

15 Table found at http://www.investinginbonds.com/learnmore. $a s p$ ?catid=3\&id=8
} 
Investors that trade in financial products rely heavily on CRA ratings. Portfolio governance and prudential regulation obligations indeed require investors to hold financial products rated by CRAs. ${ }^{16}$ As a result, debt issuers have little choice but to request ratings from the CRAs in exchange for a price. ${ }^{17}$ Moreover, given investors' constant quest for high quality and independent assessments, debt issuers typically solicit ratings from two or three CRAs. ${ }^{18}$ CRAs are thus commonly depicted as the "gatekeepers" of financial markets. ${ }^{19}$

In recent years, the "issuer pays" model has been in the line of fire. A popular analogy compares CRAs to teachers being paid by their students. ${ }^{20}$ For fear of losing business, CRAs would be reluctant to give poor grades to debt issuers. ${ }^{21}$ This conflict of interest was arguably at the core of the Subprime and Enron scandals, with junk bonds still assigned investment grades by CRAs days before the crisis began to unravel. That said, moving from the "issuer pays" to an "investor pays" business model appears unworkable in practice. This is because ratings are public goods. Once a rating has been disclosed to an investor, there is nothing - in particular in today's state of technological development - to do to prevent the subsequent dissemination of the ratings (through the "talk of the town", the press, leaks from the staff) to other investors. As a result, any investor contemplating to order a rating would eventually be discouraged to do so: (i) for fear that other investors will subsequently acquire the information for free; and (ii) anticipating that he will be able to free-ride on other investors' rating orders. $^{22}$

Occasionally, CRAs also issue unsolicited ratings based on publicly available information only. No consideration is provided by the debt issuer for such ratings. ${ }^{23}$ It is often advanced that CRAs issue unsolicited ratings with a view to increasing their customer base. Debt issuers that have been unwillingly rated might be incentivized to become customers of CRAs, so that their rating is based on more accurate data in the future.

\footnotetext{
${ }^{16}$ OECD, p.57.

${ }^{17} \mathrm{~J}$. Hunt, "Credit rating agencies and the worldwide credit crisis: the limits of reputation, the insufficiency of reform, and a proposal for improvement", Columbia Business Law Review, 2009, 1, pp. 109-209.

${ }^{18}$ European Securities Markets Expert Group (ESME), The Role of Credit Rating Agencies ESME's report to the European Commission, June 2008, p. 3, http://ec.europa.eu/internal_market/securities/docs/esme/report_040608_en.pdf

${ }^{19}$ OECD, p.16.

${ }^{20}$ J. Rega, supra. Other analogies can be drawn: the situation of CRAs is comparable to food/drugs safety agencies being remunerated by food and drug manufacturers.

${ }^{21}$ On ratings, but also on other activities, such as consultancy services, etc. CRAs occasionally advise on the creation of financial products (e.g. securities), and can thus be reluctant to assign poor grades to products they have helped creating.

${ }^{22}$ Current remedial proposals thus include for instance a fine-tuning of the "issuer pays" model or move towards "platform pays" model, where issuers can no longer choose their rating agencies.

${ }^{23}$ They generally concern sovereign bonds, although many countries have contractual relationships with CRAs.
} 
Finally, CRAs also generate revenue from subscription fees for their publications or from consultancy and advisory services. ${ }^{24}$ CRAs for instance help debt issuers design financial products.

Regulatory framework - Since many years, the "Big Three" CRAs have enjoyed regulatory protection. In 1975, the US Securities and Exchange Commission ("SEC") established the "national recognized statistical rating organizations" status (NRSROs), and grandfathered Moody's, S\&P and Fitch into such category. ${ }^{25}$ By virtue of specific legal requirements, debt issuers and other financial institutions active on US markets had to be rated by NRSROs. ${ }^{26}$ As a result, CRAs enjoying the NRSROs status became, and still are today, compulsory trading partners for very many US corporations. Similar pieces of legislation have been in force in the EU (such as the Basel II standardized approach for credit assessment). ${ }^{27}$ Interestingly, the number of appointed NRSROs increased over time. ${ }^{28}$ In 2010, there were ten NRSROs. That said, Moody's, S\&P and Fitch represent, by and large, the market standards. ${ }^{29}$

Sovereign debt - CRAs also rate sovereign States. Similarly to corporate ratings, the remuneration of sovereign ratings is not uniform. Not all countries have contractual relationships with the CRAs, and thus pay for ratings. ${ }^{30}$ In principle, countries pay for the ratings of the specific bonds they issue. But countries normally do not pay for the general, unsolicited ratings which are assigned to them by the CRAs.

Notwithstanding this, sovereign ratings exhibit significant differences from corporate ratings. They are due to the specific features of States in their position as borrowers. On the one hand,

\footnotetext{
${ }^{24}$ Standard \& Poor's for subscribers only publication is The Outlook. It is published on a weekly basis (http://www.spoutlookonline.com/); Fitch's monthly publication is the Global Ratings Directory (http://www.fitchratings.com/jsp/corporate/ProductsAndServices.faces?context=2\&detail=14); Moody's issues several publications on a regular basis, most of which are available free of charge (http://www.moodys.com/sites/products/DefaultResearch/2007400000597716.pdf).

${ }^{25}$ L. White, "The credit rating industry: an industrial organization analysis", Prepared for the Conference on "Rating Agencies in the Global Financial System" to be presented at the Stern School of Business, 1 June 2001, 20 April 2011, p. 11 (http://www.antitrustinstitute.org/node/10356).

${ }^{26}$ In the EU, CRAs play a similar role. "Based on the Capital Requirement Directive, the Committee of European Banking supervisors (CEBS) has issued non-legally binding guidelines on the recognition of external credit assessment institutions.” J. de Haan and F. Amtenbrink, op. cit.,, p. 7.

${ }^{27}$ Patrick Van Roy, "Credit Ratings and the Standardised Approach to Credit Risk in Basel II", ECB Working Paper Series, N517/August 2005.

${ }^{28}$ During the 25 years that followed the creation of the NRSROs category, the SEC designated only four additional firms as NRSROs. However, mergers among the entrants and with Fitch caused the number of NRSROs to return to the original three by year-end 2000.

${ }^{29}$ L. White, “The Credit Rating Agencies", Journal of Economic Perspectives, Volume 24, Number 2, Spring 2010 , pp. 217 and 222.

30 European Commission, Public Consultation on Credit Rating Agencies, 5 November 2010 p. 14 (http://ec.europa.eu/internal_market/consultations/docs/2010/cra/cpaper_en.pdf).
} 
unlike firms, States cannot go bankrupt. States benefit from a monopoly on the legitimate use of violence and can thus coerce citizens to pay taxes. ${ }^{31}$ This makes sovereign debt a safe investment. On the other hand, unlike firms, States cannot be coerced to pay their debts (unless war is waged). Knowing this, States might just be unwilling to pay their debts. This makes sovereign debt a risky investment.

Against this background, the methodology employed to rate sovereign debt cannot be confined to a quantitative review of States' finances. It must also embrace their willingness to pay. ${ }^{32}$ CRAs thus scrutinize a range of additional qualitative factors such as the State's institutional strength, political stability, fiscal and monetary flexibility and economic vitality. ${ }^{33}$ This methodological peculiarity is the main distinctive feature between sovereign and corporate ratings.

\section{The Case for Antitrust Intervention}

A variety of specific regulatory remedies have been discussed to address the risks of errors, "cliff effects" and financial instability arising from CRAs' sometimes ominous predictions. In contrast, policy makers have expressed little interest in antitrust intervention, although many of them have apportioned blame to the weak degree of competition that prevails in the industry. This section shows that there is a case to be made for antitrust intervention in the credit rating industry. First, CRAs exhibit prima facie features of significant market power ("SMP"), which is the main target of antitrust policy (A). Second, antitrust intervention has a number of intrinsic advantages over other remedial routes, and can tackle several issues which sector specific regulatory proposals fail to address (B).

\section{A. The Prima Facie Features of Significant Market Power}

\section{Significant Market Power, Information Goods and Reputational Damage}

Antitrust law combats SMP. Firms holding SMP ("SMP firms") can profitably set prices at levels that significantly exceed costs. As a result, those customers whose reservation price is (i) inferior to the SMP firm's price; (ii) and superior to the SMP firm's costs are not served.

\footnotetext{
${ }^{31}$ M. Weber, Politics as Vocation, in the Vocation Lectures, Hackett Publishing, 2004, who defines the State as "a human community that successfully claims the monopoly of the legitimate use of physical force within a given territory". In addition, in the globalized XXIth century economy, many States have become "too big to fail" and a country's default represents a great systemic risk for other States. Hence, government and international institutions are implicitly bound to rescue States on the brink of bankruptcy.

${ }^{32}$ This factor reflects the risk of State default if the social/political cost of tax increases is too heavy.

${ }^{33}$ Those factors lead CRAs to also hire groups of political scientists in addition to the usual teams of analysts. Moreover, it ought to be noted that a country's debt repayment track record is an important indicator of willingness to pay. J. de Haan and F. Amtenbrink, op. cit., p. 10.
} 
This is a problem because the SMP firm could render the share of demand that is not served better-off without itself being worse-off (i.e. make a loss). ${ }^{34}$ Hence, SMP firms may inflict allocative inefficiency on society - a situation referred to as a "deadweight loss" (see grey triangle below) - and thus represents a grave threat to economic welfare, and in particular consumer welfare.

SMP is often associated with situations of entrenched monopoly positions or of secret, organized conspiracies (e.g. cartels). Economists consider, however, that SMP can arise out of such polarised situations, particularly in situations of narrow oligopoly protected by barriers to entry/expansion. In certain concentrated markets, oligopolists can raise prices, simply because customers cannot sanction them by diverting orders towards other players.

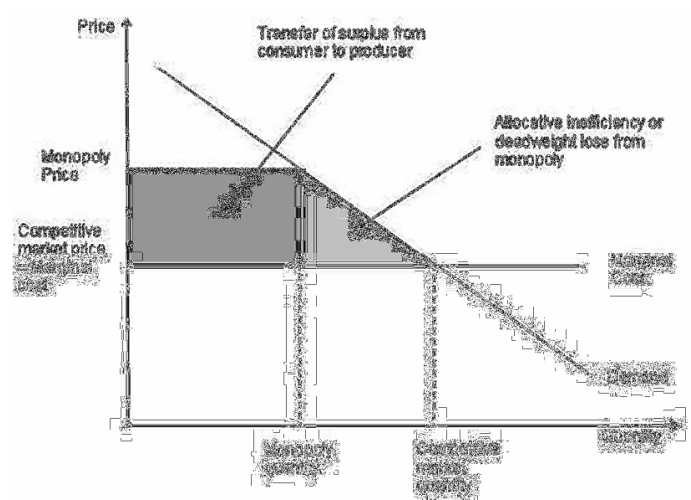

Figure 1 - The allocative inefficiency of SMP

Besides the textbook depiction of SMP as the ability to engage in above-cost pricing, competition economists consider that SMP can take a variety of forms, such as output reductions, limitations in innovation and advertisement expenditures, deterioration of product/service quality, etc. ${ }^{35}$ Since the early 20th century, a plethora of economic studies have attempted to represent the multifaceted dynamics of competition and market power across industries.

With this background in mind, the economic literature on "information goods" provides a suitable framework for analyzing competition and market power in the credit rating industry. Put simply, an information good is a commodity whose main value is derived from the

\footnotetext{
${ }^{34}$ Given that those firms can freely increase their profits through price hikes, they have little, if any, incentives to cut costs (productive inefficiency) or to innovate (dynamic inefficiency) to attract new customers.

${ }^{35}$ P. Hofer and M. Williams, "Minding Your Ps and Qs : Moving Beyond Conventional Theory to Capture the Non Price Dimensions of Market Competition", in L. Wu (Ed.), Economics of Antitrust: Complex Issues in a Dynamic Economy, NERA Economic Consulting (2007).
} 
information it contains (e.g. press, software, books, etc.). ${ }^{36}$ Credit ratings fall squarely within such category of good: they convey information on the creditworthiness of issuers of financial products.

Importantly, information goods respond to specific competitive dynamics. First, on information markets, price is not the sole driver of competition. Suppliers compete almost equally, if not more, on the qualitative features of the information (e.g. accuracy, veracity, timeliness, etc.). And in the credit rating industry, market players compete predominantly on the accuracy of their valuations. As one observer puts it: "What investors want is forecast accuracy. At present they have no simple or straightforward way of doing that, (though large investors might do so by comparing the historical records of each of the large CRAs)."37

Second, information goods are experience goods. Customers cannot assess from the outset their ability to satisfy demand needs (textbook examples of experience goods include legal services, computer programmes, books, etc.). ${ }^{38}$ Hence, customers' orders are often guided by reputation on those markets. According to many observers, this reputational feature is of particular relevance in the credit rating industry. S\&P has been reported to claim that "reputation is more important than revenues". 39

Forecast accuracy and reputation thus drive competition in the credit rating industry. In a hypothetically competitive industry, high forecast accuracy should build a good reputation (amongst investors) which in turn should grow market share (with issuers). By parity of reasoning, poor forecast accuracy should lead to reputational damage (amongst investors) which should eventually translate into loss of market share (with issuers) and possibly lead to market exit. ${ }^{40}$ In this sense, the CRA industry is a typical example of a "two-sided market",

\footnotetext{
${ }^{36}$ C. Shapiro and H. Varian, Information Rules, Harvard Business School Press, Boston, Massachusetts, 1999 seem to define information goods as "anything that can be digitized" and that is made the object of economic transactions (p.3).

${ }^{37}$ C. Goodhart, "How, if at all, should Credit Ratings Agencies (CRAs) be Regulated?", LSE Financial Markets Group Paper Series, special paper 181, June 2008, p. 32 http://www2.1se.ac.uk/fmg/documents/specialPapers/2008/sp181.pdf. Adding that "So most investors fall back on reliance on brand names, which reinforces oligopoly".

${ }^{38}$ OECD, p.7: "credit ratings are experience goods i.e. the quality of the rating is only revealed ex-post using a large sample. Simply because a default does not occur it does not mean that a good rating should be given. Therefore reputation for quality built on a long track record is the crucial competitive advantage".

${ }^{39}$ See B. Becker and T. Milbourn, op. cit. and their references p. 5 (quoting also former executive vice president of Moody's Thomas McGuire: “what's driving us is primarily the issue of preserving our track record. That's our bread and butter'').

${ }^{40}$ The demise of the big auditing firm Arthur Andersen in the wake of the Enron bankruptcy in 2002 provides a very good illustration of this.
} 
where reputation on one side of the market (investors) drives sales on the other side of the market (issuers). ${ }^{41}$

Now, in an industry subject to SMP, the virtuous circle of competition is broken. A CRA's inability to provide accuracy in its forecasts, and the ensuing reputational damage it causes amongst investors does not translate into lower sales to issuers. This is because absent competition from actual or potential competitors, issuers have nowhere to divert ratings orders.

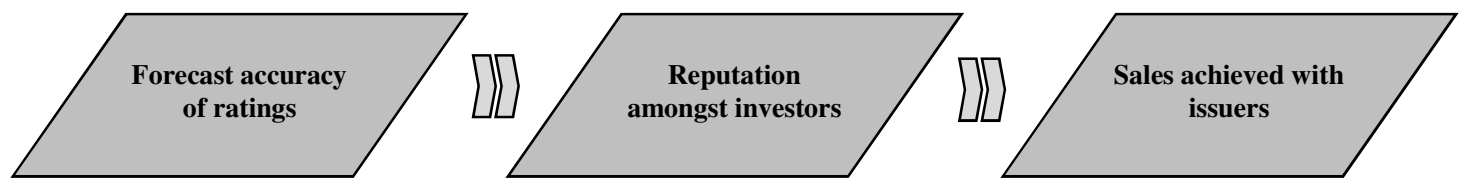

As will be seen below, there are grounds to believe that the credit rating industry is susceptible to situations of SMP. ${ }^{42}$ Beyond classic structural factors such as market concentration and barriers to entry/expansion, its track record in terms of ratings accuracy and reputational damage is consistent with the existence of SMP.

\section{The Structural Features of SMP: Market Concentration and Entry Barriers}

Several structural features of the credit rating industry support a suspicion of SMP. To start with, the credit rating industry is often described as a "shared", "narrow" oligopoly. ${ }^{43}$ Market concentration is extremely high. Moody's and S\&P are reported to hold $80 \%$ of the market. ${ }^{44}$ Fitch has a market share of approximately 15\%. With this, the Herfindahl-Hirschmann Index ("HHI") lies at around 3400, a level which generally triggers the interest of competition authorities. $^{45}$ Of course, those figures fail to reflect the existence of 74 CRAs across the world. However, most of those CRAs are not active on a global scale or simply rate specific products. Moody's, S\&P and Fitch are the sole global, multi-service CRAs. ${ }^{46}$

\footnotetext{
${ }^{41}$ A two-sided market can be defined as an economic platform that has two distinct groups of user that provide one other with network benefits (e.g. payment card systems).

${ }^{42}$ Subject to the various informational caveats that should apply to any verification of the existence of SMP.

${ }^{43}$ OECD. pp. 14 and 39.

${ }^{44}$ OECD. p. 12.

45 Assuming that one firm holds the remaining 5\%, the upper bound of the HHI is $40^{2}+40^{2}+15^{2}+5^{2}=3450$. Assuming that 5 firms hold respectively $1 \%$ of the remaining $5 \%$, the lower bound of the HHI $40^{2}+40^{2}+15^{2}+$ $1^{2}+1^{2}+1^{2}+1^{2}+1^{2}=3430$.

${ }^{46}$ They have a uniquely broad product coverage, which makes them a priority point of reference for investors. See IMF, Box 3.1.
} 
Interestingly, some observers have even used the notion of "partner monopoly" to describe the CRAs' market position. ${ }^{47}$ Since many issuers solicit two (or more) ratings, each of the "big three" CRAs often serves the entire market. Hence, the credit rating industry would comprise a series of partner, or adjacent, monopolies. In the words of economists, the ratings provided by the "big three" CRAs would not be substitutes for one another from the viewpoint of issuers. In this sense, issuers are in the same position as sellers of other services (e.g. hotels, restaurants, music artists, etc.) who seek to be referenced and rated in all available guides, directories, journals, etc. (e.g. gastronomic guides, tourist guides, music magazines, etc.).

Second, the credit rating industry is characterized by high barriers to entry/expansion. Those obstacles to entry/expansion have been abundantly documented in the economic literature and it would be beyond the scope of this paper to discuss them here. Without wading into too much detail, there are five types of barrier to entry/expansion that protect the "big three" from competition: (i) informational expertise, including the incumbent CRAs' control over a wealth of strategic information on issuers, and the time needed for prospective entrants to acquire such information; ${ }^{48}$ (ii) brand loyalty towards incumbent CRAs in a market where experience matters; ${ }^{49}$ (iii) transaction costs savings achieved by issuers in dealing only with a few CRAs; $^{50}$ (iv) investors' cognitive limits, including their unwillingness to spend large resources to understand, interpret and compare many different rating standards; ${ }^{51}$ and (v) regulatory obstacles in the US, Europe and Japan where only a limited number of CRAs (respectively 10, 4 and 5) are officially recognized as credit assessment institutions. ${ }^{52}$

\footnotetext{
${ }^{47}$ V. Padelli, "A Cerberus stands at the Doors of the Financial System: a New Challenge for the Regulation Authorities", mimeo, p.11.

${ }^{48}$ IMF, p. 98

${ }^{49}$ L. White, "The Credit Rating Agencies", op. cit., p. 217. The market for credit analyses is one "where potential barriers to entry like economies of scale, the advantages of experience, and brand name reputation are important features".

${ }^{50}$ K. Lannoo, op. cit., p. 2 "Rating agencies provide this information and thus provide huge savings in transaction costs. However, not many ratings agencies can exist, as transaction savings would disappear"; OECD, p. 7. "Corporate issuers build a trust relationship with one or two CRAs but are unwilling to be rated by more. However building this relationship involves valuable executive management time".

${ }^{51} \mathrm{~K}$. Lannoo, op. cit., p. 2: investors themselves might have some preference for a concentrated market because if "dozens of ratings agencies were active, market participants and policy-makers might fund many ratings for each borrower and this would make it also difficult for borrowers to provide a clear signal to the market about their creditworthiness". OECD, p.7: "Investors value comparability and consistency of ratings across geographical segments and instruments. Ratings from a given CRA provide a common standard to interpret risk. Investors are unwilling to spend large resources to interpret many different standards, all else equal, the larger the "installed base" of ratings from a given CRA, the greater the value to investors".

${ }^{52}$ See IMF, 2010, Box 3.1. In addition, until 2006 in the US, the criteria used by the Securities and Exchange Commission (SEC) to designate new NRSROs remained opaque, and has thus possibly discouraged entry. L. White, "The Credit Rating Agencies", op. cit., p. 217: "in creating the NRSRO designation, the Securities and
} 
To a certain extent, the growth of Fitch as a third force in the early 2000s undermines somewhat the view that there are high barriers to entry on the market. However, it ought to be noted that (i) it took decades for Fitch to achieve its market position; (ii) Fitch is primarily perceived as a fringe player by investors; ${ }^{53}$ and (iii) in the recent financial crisis, Fitch has been the most seriously impacted CRA, which suggests that its market position remains quite fragile. $^{54}$

3. The Behavioral Performance of SMP: Poor Rating Quality and Ineffective Reputational Discipline

The performance of the credit rating industry in recent years is also consistent with the distinguishing features of SMP. As explained previously, the forces that shape competition in the credit rating industry are closely linked with ratings accuracy and reputational issues. ${ }^{55}$ In a competitive industry, CRAs are supposed to fight for market share on the basis of ratings accuracy and reputation. CRAs strive to avoid ratings errors that undermine reputation, and trigger retaliation from customers who relocate rating orders to actual or potential competitors, sponsor entry or - although less probable - vertically integrate to internalize the ratings function. In contrast, in an industry subject to SMP, CRAs that make rating errors and

Exchange Commission had become a significant barrier to entry into the bond rating business in its own right. Without the benefit of the NRSRO designation, any would-be bond rater would likely remain small-scale. New rating firms would risk being ignored by most financial institutions (the "buy side" of the bond markets); and since the financial institutions would ignore the would-be bond rater, so would bond issuers (the "sell side" of the markets)." See also p.222: "In early 2003 the SEC designated a fourth "nationally recognized statistical rating organization”: Dominion Bond Rating Services, a Canadian credit rating firm. In early 2005 the SEC designated a fifth NRSRO: A.M. Best, an insurance company rating specialist. The SEC's procedures remained opaque, however, and there were still no announced criteria for the designation of a NRSRO. Tiring of this situation, Congress passed the Credit Rating Agency Reform Act, which was signed into law in September 2006. The Act instructed the SEC to cease being a barrier to entry, specified the criteria that the SEC should use in designating new "nationally recognized statistical rating organizations," insisted on transparency and due process in these SEC's decisions, and provided the SEC with limited powers to oversee the incumbent NRSROs-but specifically forbade the SEC from influencing the ratings or the business models of the NRSROs".

${ }^{53}$ Bongaerts, D.G.J., Cremers, K.J.M. \& Goetzmann, W.N. (2011). Tiebreaker: Certification and Multiple Credit Ratings. The Journal of Finance, forthcoming (reporting that Fitch plays the role of a "tie breaker" for investors when S\&P and Moody's achieve inconsistent ratings).

${ }^{54}$ OECD, p.12.

${ }^{55}$ For years, the threat of reputational damage has been perceived as a reliable disciplinary mechanism in the credit rating industry. The basic idea was then that "agencies have an overriding incentive to maintain a reputation for high-quality, accurate ratings. If investors were to lose confidence in an agency's ratings, issuers would no longer believe they could lower their funding costs by obtaining its ratings. As one industry observer as put it, "every time a rating is established, the agency's name, integrity, and credibility are on the line and subject to inspection by the whole investment community"". Quite ironically, the comment then concluded: "Over the years, the discipline provided by reputational considerations appears to have been effective, with no major scandals in the ratings industry". R. Cantor and F. Packer, "The Credit Rating Industry", FRBNY Quarterly Review, Summer-Fall 1994, p. 4. A similar view has been expressed by J. Coffee: "These professionals develop "reputational capital" over many years and many clients that leads investors to rely on them, in part because investors know that the gatekeeper will suffer a serious reputational injury if it is associated with a fraud or unexpected insolvency". J. Coffee, Testimony Before the Senate Banking Committee On September 26, 2007 "The Role and Impact Of Credit Rating Agencies on the Subprime Credit Markets", p. 1 . 
endure reputational losses face, however, no retaliation from customers and end up maintaining their market position and profits. ${ }^{56}$ In our model, CRAs can commit type I (unjustified downgrading or underrating) and/or type II (unjustified upgrading or overrating) ratings errors.

Against this background, the history of the credit rating industry provides some empirical evidence of SMP. ${ }^{57}$ With hindsight, the "big three" CRAs systematically failed to forecast, or underestimated, the severe financial events that have damaged the global economy over the past fifteen years. ${ }^{58}$ CRAs did not foresee the Asian crisis in $1997 .{ }^{59}$ They also failed to predict the high-profile corporate failures of Enron, WorldCom and Global Crossing. ${ }^{60}$ More recently, the CRAs still assigned an A rating to Lehman Brothers only a month before its collapse. ${ }^{61}$ And just days before the Subprime crisis unraveled, a large number of financial products which are now rated "junk" enjoyed the highest investment rates in the ratings of the various CRAs (see figure 2 hereafter). ${ }^{62}$

\footnotetext{
${ }^{56}$ In the conventional SMP model described above, a firm could be said to hold SMP if, failing to satisfy market demand, it nonetheless achieved supra-competitive profits. Now, if we transpose this to the credit rating industry - where demand satisfaction is quality-driven rather than price-driven - a SMP situation should be deemed to arise when despite ratings errors and reputational losses, a CRA faces no change in its market position and profits.

${ }^{57}$ Given the lack of data, we cannot review here the consequences of the recent, serious error of S\&P, which decided to downgrade the US government rating despite a \$2 trillion error.

${ }^{58}$ In addition, CRAs have also been criticized for responding with a considerable time lag, i.e. ratings were not immediately downgraded once the problems in the sub-prime market became clear.

59 The CRAs later exacerbated the crisis when they downgraded the countries in the midst of the financial turmoil. Bank of England, p.8 (and references).

${ }^{60}$ P. Deb, M. Manning, G. Murphy, A. Penalver and A. Toth, Whither the credit rating industry?, Financial Stability Paper No. 9 - March 2011, Bank of England, p.8 (and references). Enron was still rated investment grade until four days before it declared bankruptcy. Similarly, both WorldCom and Global Crossing were still rated investment grade not long before their respective failures.

${ }^{61}$ A. J. Bahena, "What Role Did Credit Rating Agencies Play in the Credit Crisis?”, mimeo March 2010.

${ }^{62}$ IMF, 2010, Figure 3.1.: over three quarters of all private-label residential mortgage backed securities issued in the United States from 2005 to 2007 that were rated AAA by S\&P are now rated below BBB-, that is, below investment grade.
} 
Figure 3.1. Ratings of AAA-Rated US. Mortgage-Related

Securities

In percent of SSP's originally rated $2005-07$ is suanceas of

Jully 31,2010 )

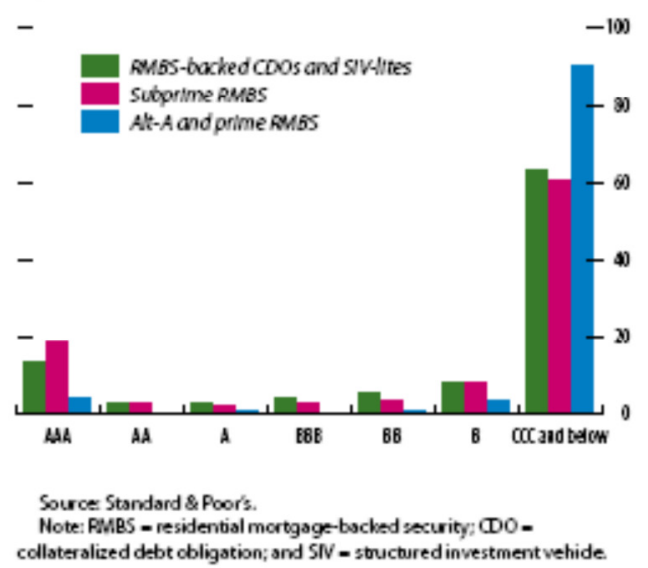

Figure 2-2010 rating of former AAA-rated mortgage backed securities

Without doubt, such type II errors inflicted reputational harm on the CRAs. ${ }^{63}$ Yet, unlike in a competitive market, they were without real consequences. Despite the Internet Bubble, Enron's bankruptcy and the Subprime crisis, the "big three" CRAs have maintained very significant and symmetrical market shares. ${ }^{64}$ Industry structure has remained stable, with little, if no, entry attempts. Finally, the "big three" CRAs have maintained large profits despite a small decline following the Subprime crisis in 2007 (see figure 3 hereafter). ${ }^{65}$

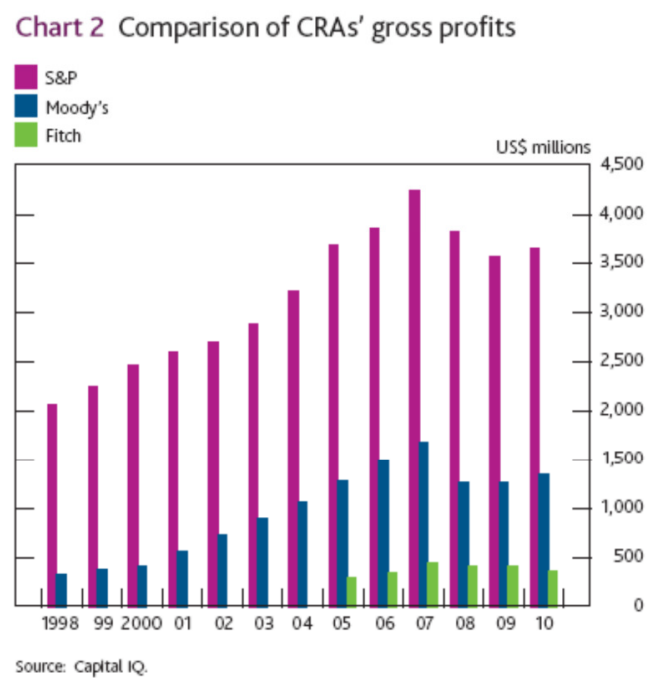

\footnotetext{
${ }^{63}$ For instance, observers report that the stock price of Moody's reacts negatively to rating actions that are perceived to indicate low rating quality . G. Löffler, "Can Market Discipline Work in the Case of Rating Agencies? Some Lessons from Moody's Stock Price", University of Ulm, October 2009, p. 19.

${ }^{64}$ In relative terms, the various CRAs have achieved similar profits throughout the years, which indicate that market positions have remained very stable. See figure2.

${ }^{65}$ Figure taken from P. Deb, M. Manning, G. Murphy, A. Penalver and A. Toth, op. cit. Forecasts also suggest that the "big three" CRAs' profits should increase in upcoming years. See A. van Duyn, Rating agencies bullish on year ahead, Financial Times, 03.02.2011.
} 
Figure 3 - CRAs profits ${ }^{66}$

Empirical evidence thus suggests that the reputational harm mechanism which should discipline CRAs in the event of ratings errors is ineffective. ${ }^{67}$ In our opinion, the key explanatory factor for this lies in the existence of SMP, and in the weak degree of competition that prevails on the market. 68 Given the close identity of the "big three" CRAs' ratings, as well as the need to rely on 2 or 3 ratings, it is futile for disgruntled users (investors and issuers) to threaten to divert ratings orders from one CRA to the other. Moreover, disgruntled users cannot threaten to sponsor new entrants or to vertically integrate in light of the high barriers to entry discussed above. Insulated from competition, CRAs can make senseless predictions without ever being sanctioned by users, who are wholly captive of their evaluations. In summary, the "big three" CRAs enjoy a classic "situational rent", which is the paradigmatic example of SMP.

\section{Alternative Theories}

A number of studies have a different reading of the functioning of the credit rating industry. We review them in turn hereafter.

\subsection{Ineffective Rules on Civil Liability generate Ratings Negligence}

The view often holds sway that the problem of the credit rating industry does not originate in a lack of competition, but rather in the fact that CRAs are immune to civil (or criminal) liability in the event of rating errors. ${ }^{69}$ Insulated from such constraint, CRAs' have little incentive to act with restraint and caution in their ratings. ${ }^{70}$

\footnotetext{
${ }^{66}$ Source, P. Deb, M. Manning, G. Murphy, A. Penalver and A. Toth, supra p.8.

67 J. de Haan and F. Amtenbrink, op. cit., p.8. Many commentators share the view that the reputational mechanism currently fails to play its role: "it may be argued that CRAs must safeguard their credibility with investors as their ratings would otherwise be of no value in the market. In this perspective CRAs must balance any short-term gain from satisfying the issuer with its long-run reputation in the market. Yet, it is doubtful whether the potential loss of reputation sufficiently restrains CRAs and can indeed function as an effective form of sanction.

${ }^{68}$ Other observers agree that a lack of competition is the key factor preventing reputation from producing any kind of constraining effect on CRAs. See S. Utzig, "The Financial Crisis and the Regulation of Credit Rating Agencies: A European Banking Perspective", ADBI Working Paper Series No. 188, January 2010, p. 6 "Selfregulation does not work effectively when the pressure of reputation as a controlling power exists only to a limited degree due to a lack of competition". U. Blaubrock, "Control and Responsibility of Credit Rating Agencies", Electronic Journal of Comparative Law, December, vol. 11.3, 2007, p. 6 (http://www.ejcl.org) ("the dominant agencies do not have to fear any significant qualitative cut-throat competition, with the consequence that the temptation exists to keep their resource input down.").

${ }^{69}$ F. Partnoy, "How and Why Credit Rating Agencies Are Not Like Other Gatekeepers", Legal Studies Research Paper Series, Research Paper No. 07-46, May 2006, p. 61. Like the media, CRAs have long been protected from litigation for their opinions and analyses (except where a voluntary fraud could be evidenced). The Dodd-Frank Act passed in 2010 aimed at redressing this litigation privilege. Dodd-Frank Wall Street Reform and Consumer Protection Act, Pub.L. 111-203, H.R. 4173, SEC. 933; D. Martin and M. Franker, "Dodd-Frank Issue Brief: Requirements Affecting Credit Rating Agencies", Council of Institutional Investors, April 2011, p. 2,
} 
This, however, does not mean that there is no SMP. Rather, the lack of effective liability for rating errors further exacerbates the competition problem outlined above. In the credit rating industry, disgruntled users are deprived of both the economic - i.e. competition - and legal i.e. civil liability proceedings - retaliation mechanisms available on most markets.

As things stand, at any rate, stronger liability rules are unlikely to ever alter the incentive structure of CRAs. In most jurisdictions, civil (or criminal) liability only kicks in at a certain threshold of negligence or willful misconduct. Hence, stronger liability rules can correct little but the crudest rating errors, and are wholly ineffective in eradicating less blatant mistakes (rating inaccuracies, inexpediencies, etc.). Moreover, CRAs' immunity from civil (or criminal liability) is often justified on the ground of the right to free speech, which is protected by constitutional statutes. ${ }^{71}$

\subsection{Competitive Entry degrades Ratings Quality}

Overview of the Literature - Several economists make the counter-intuitive point that increasing competition in the credit rating industry is undesirable. BECKER and MILBOURN adduce empirical evidence that the entry of Fitch on the market caused a decrease in ratings quality through "ratings inflation" (upgrading of rated securities without any apparent justification). ${ }^{72}$ To explain this puzzling finding, the authors claim that the jolt of competition instilled by the entry of Fitch reduced the profitability prospects of incumbent CRAs. With weaker profitability forecasts, incumbent CRAs thus reduced investments in costly short term reputational activities, i.e. the production of high quality information (an "incentive to invest" problem). ${ }^{73}$ Alternatively, the authors argue, perhaps more convincingly,

(http://cii.org/UserFiles/file/resource\%20center/publications/Dodd-Frank\%20-

\%20Requirements\%20Affecting\%20CRAs.pdf). However, the current Republican majority is working on a Bill which would reinstate the prior legal regime. K. DRAWBAUGH, "Challenges to Dodd-Frank surface in Congress", Reuters, 15 March 2011 (http://www.reuters.com/article/2011/03/15/us-financial-regulation-debitidUSTRE7273T120110315). In Europe, see European Commission, Public Consultation on Credit Rating Agencies, op. cit., p. 24. In the EU, work is currently under way to study whether it is necessary to introduce a civil liability regime to ensure that CRAs are liable for the damage caused by ratings errors. At the national level only one Member State has recently introduced a specific civil liability regime for CRAs: "In other Member States there is ongoing discussion whether CRAs could be held liable vis a vis investors and in a third group of Member States civil liability of CRAs towards investors seems to be legally impossible". More fundamentally however, the culture of private enforcement is less widespread in the EU. Hence, the constraint that would be exercised by civil liability rules in the EU would probably be less effective than in the US.

${ }^{70}$ OECD, p. 16.

${ }^{71}$ Under the First Amendment of the US constitution and Article 11 of the Charter of Fundamental Rights of the EU. Several rulings have actually accepted the idea that the CRA business is financial publishing and have validated the argument. Idem, p. 66.

${ }^{72}$ B. Becker and T. Milbourn, "How did increased competition affect credit ratings ?", Journal of Financial Economics, 2011, forthcoming.

${ }^{73}$ However, no quantitative evidence is advanced in support of this speculation (for instance, on investments in information), and the thesis rests on the wholly disputable theoretical assumption that reputational losses are of 
that in line with increased competition, incumbent firms have sought to secure their customer base, and have thus increased their ratings to reflect issuers' preferences rather than genuine credit quality (a "revenue bias" problem). ${ }^{74}$

BONGAERTS et. al. also rely on econometrics to show that the introduction of Fitch on the market has neither improved the quality of information nor reduced uncertainty. Rather, firms primarily use Fitch ratings to bypass the negative effects of regulatory requirements when their financial product has been rated by S\&P and Moody's at opposite sides of the investment grade boundary, and might as a result not be admissible for trading with certain financial institutions (a "certification" problem).

Finally, BOLTON et al. argue formally that a monopoly is preferable to a duopoly in the credit rating industry. ${ }^{75}$ This is because a duopoly provides more opportunities for the issuer to shop around and mislead trusting investors (a "ratings shopping" problem). This latter finding, however, has been discarded by recent studies, which show that ratings shopping does not happen where ratings are unsolicited and financial information is publicly available (for instance, in the market for corporate bonds). ${ }^{76}$ The ratings shopping hypothesis is thus only relevant in a subset of markets. ${ }^{77}$

Critical Assessment - On many counts, the above studies are marred by shortcomings. ${ }^{78}$ To name but a few, rather than devising ratings quality criteria, they rely on crude and imperfect proxies. $^{79}$ Also, the representativeness of their findings is questionable, ${ }^{80}$ in particular because they do not deal with "ratings deflation" which is the new paradigm of the credit

lesser concern when there is competition. Alternative research suggests that several forces are at play, acting in diametrically opposed directions. "In fact, depending on parameters, ratings quality can be higher either under monopoly or duopoly". "Intuitively, the value of milking a reputation for current returns is higher for a monopolist. This is a force that suggests that the monopolist would produce lower quality ratings. On the other hand, the value of maintaining reputation to gain future rewards is also higher for a monopolist, suggesting that a duopolist produces higher quality ratings". H. Bar-Isaac and J. Shapiro, "Ratings Quality over the Business Cycle”, April 2010, pp. 20-21 (http://pages.stern.nyu.edu/ hbar-isa/HBJS_CRAcycle.pdf)

${ }_{75}$ B. Becker and T. Milbourn, op. cit.

${ }^{75}$ P. Bolton, X. Freixas, and J. Shapiro, 2008, “The Credit Rating Game” unpublished manuscript, p.38. In turn, rating shopping decreases the quality of ratings, through ratings inflation. V. Skreta and L. Veldkamp, 2009. "Ratings shopping and asset complexity: A theory of ratings inflation", Journal of Monetary Economics, Elsevier, vol. 56(5), pages 678-695, July.

${ }^{76}$ C. Spatt, "Discussion of 'Ratings Shopping and Asset Complexity: A Theory of Ratings Inflation"”, (2009) Journal of Monetary Economics 56, 696-699; Beckers and Milbourn, op. cit., pp.8 and 9; Bongaerts, Cremers and Goetzmann confirm this empirically.

${ }^{77}$ For instance, in structured products markets.

${ }^{78}$ For instance, one cannot rule out collusion, tacit or explicit, between the three players on "ratings inflation".

${ }^{79}$ Those studies use ratings inflation and indexation with bond prices as proxies for ratings quality. However, they fail to reflect on the substance of what makes a "good" rating for investors: expediency, consistency across rated instruments, etc.

${ }^{80}$ The study of Becker and Milbourn, for instance, only covers corporate bonds and not structured products. 
rating industry. ${ }^{81}$ Finally, those studies test an entry scenario with $\mathrm{n}+1$ firms, but provide no guidance on an entry scenario with $n+2 ; n+3$; and so on.

More fundamentally, the above theories are somewhat confusing. In fact, their authors argue in parallel that competition must generally be strengthened, and entry promoted, because it reduces oligopolistic rents and adds information on financial markets. ${ }^{82}$

Those conflicting pronouncements can nonetheless be reconciled. On close examination, what the above studies stress is that whilst competitive entry is a genuinely good thing, several industry-specific practices/regulations sabotage its welfare-enhancing effects and trigger inefficiency. PAGANO and VOLPIN provide ample evidence of this: ${ }^{83}$ the revenue bias problem arises primarily from the fact that CRAs are paid by issuers; ${ }^{84}$ the certification problem stems from regulatory instruments, which overly rely on credit ratings; the ratings shopping problem is caused by the fact that issuers need not disclose all their ratings, and can thus conceal poor ratings until they obtain a better one.

On top of this, the complexity of financial products, the protection of CRAs as official credit assessment institutions, and the lack of expertise of investors also contribute to ratings inflation dynamics. $^{85}$

Public Policy Implications - In our opinion, the above works confirm that there is a competition problem in the credit ratings sector: the industry exhibits features which distort competition, in turning market entry - an efficient, good thing - into an inefficient and negative thing. ${ }^{86}$

\footnotetext{
${ }^{81}$ Does the current cycle of "ratings deflation" corroborate or invalidate their findings? Also, is "ratings deflation" a sign of high or low ratings quality under competition?

${ }^{82}$ See IMF, p.98; Beckers and Milbourn, op. cit., p.10. According to the EU Commission, one of the main reasons for public authority intervention is to "increase competition in the rating market and increase the number of ratings per instrument so that users of ratings will be able to rely on more than one rating for the same instrument". Proposal for a Regulation of the European Parliament and of the Council on amending Regulation (EC) No $1060 / 2009$ on credit rating agencies $\{\operatorname{SEC}(2010) 678\} \quad\{\operatorname{SEC}(2010) \quad 679\} \quad / *$ COM/2010/0289 final - COD 2010/0160 */, point 4.3.2. On information wealth, one may also consider that if competition leads to lesser "vertical" investment from each CRA in information, it may be counterbalanced by a higher level of "horizontal" investment of all the CRAs in information.

${ }^{83}$ M. Pagano and P. Volpin, "Credit Ratings Failures and Policy Options”, mimeo, October 2009.

${ }^{84}$ This problem is further aggravated by the fact that issuers do not pay CRAs upfront for their rating, but rather payment is contingent on the content of the report.

${ }^{85}$ V. Skreta and L. Veldkamp, op. cit.. M. Pagano and P. Volpin, op. cit., p.9.

${ }^{86}$ The IMF said just this when it stated that "looking ahead, enhanced competition would be welcome, with a few caveats [...] measures should be taken to discourage such rating shopping, including requiring disclosure about any preliminary ratings." IMF, p.98.
} 
This implies that specific measures must complement possible interventions seeking to promote market entry (e.g. creation of new CRAs, be they public or private). ${ }^{87}$ In this context, because competition rules regulate business models that give rise to anticompetitive effects, it is not foolish to rely on such rules to address those market practices, such as the "issuer-pays" model, that prevent competitive entry from delivering efficiency. In parallel, sector specific measures can be targeted at regulatory frameworks which subvert the positive effects of entry.

To conclude, those that claim that competition is undesirable in the credit rating industry make a basic causation mistake, which is akin to prohibiting unfit, overweight persons from jogging, simply because it risks inflicting on them joint pain and other minor physical trauma. Jogging is good, but it only has health-improvement effects if carried out under a tailor-made training programme, complemented by suitable equipment and diet.

\section{Conclusion}

The credit rating industry displays symptoms of SMP. The three factors of "substantial market power" (also referred to as a "dominant position") underlined in the Commission's Guidance Communication on Article 102 of the Treaty on the Functioning of the EU (“TFEU”), are manifestly present: (i) large market position of incumbent firms; (ii) barriers to entry and expansion; (iii) lack of countervailing power. ${ }^{88}$ There is thus a patent competition problem in the credit rating industry. This problem is further compounded by the fact that several industry-specific features upset the efficiency-enhancing effects of competitive entry. At least conceptually, it is thus justified to rely on the competition rules to investigate the credit rating industry and, as the case may be, envision remedial intervention.

\section{B. Antitrust Intervention v. Sector Specific Regulation?}

\section{Background}

The CRAs' repeated ratings errors, and their possible contribution to the exacerbation of market difficulties, are no longer disputed. There is today a broad consensus amongst stakeholders that something must be done to fix the market failures that beset the credit rating

\footnotetext{
${ }^{87}$ Idem: "Enhanced competition would need to be combined with tougher measures against rating shopping".

${ }^{88}$ See Guidance Communication on the Commission's enforcement Priorities in Applying Article 82 of the EC Treaty to Abusive Exclusionary Conduct by Dominant Undertakings, C(2009) 864 final, para. 12 and following.
} 
industry. ${ }^{89}$ The question remains open however whether this should be done under sector specific regulatory instruments and/or under the competition rules. As explained previously, there is a good case for intervention under both sets of instruments.

In recent years, experts from all sides have toiled with devising sector specific regulatory proposals in relation to conflicts of interest (the flaws of the "issuer-pays" model), cliffeffects arising from portfolio governance and prudential regulations, transparency on rating procedures and methodologies, rules on official recognition as credit rating institutions, oversight ineffectiveness, civil liability regimes, etc. ${ }^{90}$

In contrast, however, stakeholders have been remarkably shy when it comes to antitrust intervention. ${ }^{91}$ Beyond high-level policy calls to dissolve the credit ratings oligopoly, ${ }^{92}$ very few competition-related remedies have been discussed. This is all the more unfortunate, given the intrinsic limits of regulatory approaches (2) and the comparative merits of competition enforcement (3).

\section{The Intrinsic Limits of Sector-Specific Regulatory Remedies}

Regulatory initiatives are fraught with effectiveness (a) and process (b) limitations.

\section{a). Effectiveness Issues}

The adoption of sector-specific regulatory instruments may have unintended anticompetitive consequences. New regulatory obligations on CRAs may further shield existing market players from external competition, through the introduction of legal barriers to entry on prospective firms (e.g. search, advice and compliance costs). ${ }^{93}$

\footnotetext{
${ }^{89}$ Although there are divergences in terms of approaches. Industry participants and sector-specific regulators seem, on the one hand, to support self regulation. On the other hand, policy representatives have voiced support for ambitious reforms which would lead to the adoption of mandatory sector specific regulatory instruments.

${ }^{90}$ Over the last few years, numerous proposals have been made to adapt the regulatory framework for CRAs. Several improvements have been introduced in EU Regulation 1060/2009 and the US Dodd-Frank Act which introduce provisions regarding the registration of CRAs, conflict of interests, transparency. Regulation No 1060/2009, 16 September 2009 on credit rating agencies, OJ, 17 November 2009, L 302/1.

${ }^{91}$ Whilst also recognizing that the lack of competition in the credit rating industry is a problematic issue. See IMF: "the significant increase over time in references to credit ratings in rules and regulations, combined with limited competition, has affected the business model of CRAs by creating a more or less "guaranteed market" with few incentives to compete on the basis of rating quality", p.94. "Looking ahead, enhanced competition would be welcome, although there are a few caveats", p.98.

${ }^{92}$ Commissioner Reding is reported to have supported "dismantl[ing] the rating agencies". Attempts to achieve dissolution can take very many forms, through the dismantlement of the existing oligopoly into smaller pieces, or with the setting up of new agencies, be they public or private. A number of Member States (Poland, Germany) as well as the EU internal market Commissioner support the creation of an EU public agency.

${ }^{93}$ K. Lannoo, Credit Rating Agencies. Scapegoat or free-riders ? ECMI Commentary No. 20/9, October 2008 , p. 3: warning that: "Functional regulation for a sector that is as specific as rating agencies could lead to undesirable side effects. It has been argued that it further strengthens the quasi-statutory role of these bodies, which may reduce their alertness. It reinforces the barriers to entry whereas the opposite should be done".
} 
But this is not all. Insofar as internal competition amongst the big three is concerned, new regulatory obligations may further chill competition through a deterioration of the oligopolists' cost structure (e.g. compliance costs). More importantly, efforts to regulate rating procedures and methodologies may restrict flexibility and innovation in the assessment of information, and in turn reduce competition ${ }^{94}$

Finally, softer approaches which promote self-regulation, best practices and industry standards are ill-suited to solve competition issues. After all, when industry players agree to abide by common standards, they voluntarily reduce the scope for competition on the market. Competition specialists know all too well that beyond the anticompetitive effects of standardization processes, such collaboration creates opportunities for market players to meet and exchange sensitive information or to implement subtle boycott strategies. This is certainly a sensible consideration to bear in mind, given the strong stakeholder support for self-regulation in current policy debates. ${ }^{95}$

\section{b). Process Issues}

The adoption of sector-specific regulatory instruments is subject to a major procedural downside. In the EU, regulatory reforms undergo a burdensome decision-making process where the various EU institutions each have a say. As a result, the passing of Directives or

\footnotetext{
${ }^{94}$ L. White, "The Credit Rating Agencies", op. cit., p. 223: "Regulatory efforts to fix problems, by prescribing specified structures and processes, unavoidably restrict flexibility, raise costs, and discourage entry and innovation in the development and assessment of information for judging the creditworthiness of bonds. Ironically, such efforts are likely to increase the importance of the three large incumbent rating agencies."

95 According to the Committee of European Securities Regulators (CESR) created by decision of the European Commission, the credit rating market should be ruled by industry standards more than by regulation: "CESR and market participants believe that there is no evidence that regulation of the credit rating industry would have had an effect on the issues which emerged with ratings of US subprime backed securities and hence continues to support market driven improvement. (...) CESR therefore urges the Commission as an immediate step to form an international CRAs standard setting and monitoring body to develop and monitor compliance with international standards in line with the steps taken by IOSCO." Committee of European Securities Regulators (CESR), CESR's Second Report to the European Commission on the compliance of credit rating agencies with the IOSCO Code and The role of credit rating agencies in structured finance, CESR/08-277, May 2008, p.3, http://www.cmvm.pt/CMVM/Cooperacao\%20Internacional/Docs_ESMA_Cesr/Documents/CESR_08_277.pdf The European Securities Markets Expert Group (ESME) goes in the same direction and warns against the perverse effects of any undue regulation: "full formal regulation may be counter-productive as it might be seen by users in the market place to imply a level of official endorsement of ratings which is neither justified nor feasible. ESME does not consider it is possible for regulators to put themselves in a position where they can give that level of endorsement. Even the SEC's authority in the US does not extend to the regulation of the substance of the credit ratings. Our view overall is that the incremental benefits of regulation would not exceed the costs and accordingly is not recommended." European Securities Markets Expert Group (ESME), The Role of Credit Rating Agencies ESME's report to the European Commission, June 2008, p. 22, (http://ec.europa.eu/internal_market/securities/docs/esme/report_040608_en.pdf). the EU Commission also acknowledges the risk there is that full regulation of the credit rating analysis market would send an undesirable signal to the market: "references to ratings in the regulatory framework should be reconsidered in light of their potential to implicitly be regarded as a public endorsement of ratings and their potential to influence behavior in an undesirable way." European Commission, Public Consultation on Credit Rating Agencies, op. cit., p. 5.
} 
Regulations often involves complex, protracted negotiations between the Commission, the Council, the Parliament and possibly national Parliaments. ${ }^{96}$ In addition, the intervention of several institutions offers vantage points to lobbyists. Finally, reforms take long to pass through the legislative process, but they also take long to implement. In the EU especially, regulatory reforms become only enforceable once transposed in the national legislation of the Member States. This further delays the entry into force of regulatory remedies.

\section{The Advantages of Antitrust Intervention}

Besides being conceptually attractive, the competition rules could prove instrumentally useful in the credit rating industry. The competition rules indeed have five advantages over traditional regulatory instruments.

First, antitrust investigations are subject to easy trigger mechanisms. Investigations are launched upon complaints but also ex officio by competition authorities ("CAs"). CAs do not need specific evidence of an infringement to open an investigation. In the EU, the Commission can launch sector inquiries into a particular sector of the economy "where the trend of trade between Member States, the rigidity of prices or other circumstances suggest that competition may be restricted or distorted within the common market". ${ }^{97}$ The Commission has often used this prerogative to investigate sectors where competition issues were much less obvious than in the credit rating industry (e.g. in the pharmaceutical sector). ${ }^{98}$ Once the inquiry is opened, the Commission enjoys broad investigative powers. It can request firms subject to the investigation to provide all necessary information, ${ }^{99}$ take statements, ${ }^{100}$ and inspect business premises. ${ }^{101}$ Failure to comply with the Commission's requests can lead to the imposition of hefty fines and periodic penalty payments. ${ }^{102}$

Second, antitrust infringement doctrines are flexible. Like it or not, the scope of the competition rules found at Articles 101 and 102 TFEU is open-ended. Pursuant to wellsettled case-law, the Treaty competition provisions do not prescribe an exhaustive

\footnotetext{
96 As a result, controversial regulatory proposals are often abandoned for lack of support in one of those organs. More often, regulatory proposals will be watered down during the legislative process, and end-up at the lowest common denominator.

97 Article 17 of Council Regulation 1/2003 of 16 December 2002 on the implementation of the rules on competition laid down in Articles 81 and 82 of the Treaty, OJ L 1, 4 January 2003, pp. 1-25.

${ }^{98}$ N. Petit, "Bark at the Moon? - The outcome of the EC pharmaceutical sector inquiry", Concurrences, $\mathrm{N}^{\circ} 3$ 2009, n²8154, pp. 11-25.

${ }^{99}$ Article 18 of Regulation 1/2003, supra.

${ }^{100}$ Article 19 of Regulation 1/2003 supra.

${ }^{101}$ Article 20 of Regulation 1/2003 supra.

${ }^{102}$ Articles 23 and 24 of Regulation 1/2003 supra.
} 
enumeration of unlawful behaviors. ${ }^{103}$ In addition, while the generalization of the "effectsbased" approach in EU competition law certainly raises the evidentiary burden that CAs have to overcome, it meanwhile extends the substantive scope of the competition rules to virtually any practice that produces anticompetitive effects, regardless of its form. ${ }^{104}$ As a result, the EU competition rules apprehend an increasingly wide number of business practices. They may be used to challenge problematic business models, as they were in the Microsoft cases, where the Commission objected to technological product integration and forced Microsoft to modify its marketing policy. ${ }^{105}$ Also, the development of the collective dominance doctrine under Article 102 TFEU brings an increasing number of oligopolistic markets within the realm of the EU competition rules.

Third, antitrust remedies are polymorphous. Once an infringement has been found, CAs can impose behavioral and/or structural remedies to bring it effectively to an end. ${ }^{106}$ Behavioral remedies force a firm to modify its business conduct, in the spirit of "command and control" regulation. Structural remedies are similar to "regulatory takings" which change the allocation of property rights on the market, for instance through divestiture orders. ${ }^{107}$ In practice, such remedies may also be negotiated as part of a settlement between the parties and the Commission, in exchange for the early termination of the proceedings. ${ }^{108}$ To date, CAs have devised very innovative remedies in competition cases: obligation to disclose essential technical information to competitors in the Microsoft I case; divestiture of gas transmission networks in the ENI and $R W E$ cases; obligations to provide full access to technical resolutions and related background documents used in the ship classification market in the International Association of Classification Societies case; decrease of the royalty rates charged for intellectual property rights in the Rambus case; reduction of the duration of contracts in the $D S D$ case; etc. The plasticity of competition remedies could thus prove useful in the credit rating industry, where reform proposals primarily purport to modify the CRAs" "issuer pays" business model or to impose transparency obligations on ratings procedures/methodology, etc.

\footnotetext{
${ }^{103}$ ECJ, 6/72, Europemballage Corporation and Continental Can Company v. Commission, ECR 1973 p.215.

${ }^{104}$ N. Petit, "From Formalism to Effects? The Commission's Communication on Enforcement Priorities in Applying Article 82 EC", (2002) 32 World Competition, 485. Of course, there are still some formal requirements, such as proof of an "agreement, concerted practice or decision by association of undertakings" under Article 101 TFEU. Yet, with the effects based approach, even such requirements tend to be less strict.

${ }^{105}$ N. Petit and N. Neyrinck, "Back to Microsoft I and II: Tying and the Art of Secret Magic", Journal of European Competition Law \& Practice (2011) 2(2): 117-121.

${ }^{106}$ Article 7 of Regulation 1/2003, supra.

${ }^{107}$ In principle, behavioral remedies should prevail over structural ones. Idem: "Structural remedies can only be imposed either where there is no equally effective behavioural remedy or where any equally effective behavioural remedy would be more burdensome for the undertaking concerned than the structural remedy".

${ }^{108}$ Article 9 of Regulation 1/2003, supra.
} 
Fourth, antitrust enforcement is very efficient. Unlike regulatory reforms which are often contingent on subsequent national transposition, CAs' decisions are directly applicable. In addition, in the EU, competition decisions are crafted by independent CAs which operate at arm's length from national governments and parliaments. Hence, little of the interferences and delays described above arise in competition proceedings. ${ }^{109}$ Finally, compliance with the competition rules is mandatory, and is ensured through a system of stringent penalties which range from administrative fines on firms to individual sanctions (fines, director disqualification and jail sentences). ${ }^{110}$ At the EU level, firms guilty of an infringement of Article 101 or 102 TFEU can be fined up to $10 \%$ of their annual global turnover. ${ }^{111}$ In addition, firms that do not comply with a Commission decision finding an infringement, ordering remedies or imposing commitments can be subject to periodic penalty payments of up to $5 \%$ of their daily global turnover. ${ }^{112}$

Fifth, antitrust institutions are less exposed to risks of capture by interest groups than sector specific regulators. ${ }^{113}$ CAs exercise oversight duties over the entire spectrum of the economy. Their future is thus less dependent on the continued support of a particular industry. ${ }^{114}$ In addition, CAs only intervene intermittently in specific economic sectors. Hence, CA officials share less personal bonds with industry members. Moreover, given their general expertise, they are less subject to "revolving doors" practices. Those considerations are important in the financial industry, where suspicions of complacency by regulators vis-à-vis CRAs are common. $^{115}$

\footnotetext{
${ }^{109}$ In fact, competition proceedings may only last a few months. This is particularly true in cases leading to commitments under Article 9 of Regulation 1/2003.

${ }^{110}$ And this is not to mention the increased availability of damages for competition law infringements before the national courts.

${ }^{111}$ Article 23(2) of Regulation 1/2003, supra.

${ }^{112}$ Article 24 of Regulation 1/2003, supra.

${ }^{113}$ On regulatory capture, see G. Stigler, "The Theory of Economic Regulation", The Bell Journal of Economics and Management Science, Vol. 2, No. 1, Spring, 1971, pp. 3-21 ; J.J. Laffont and J. Tirole," The Politics of Government Decision-Making: A Theory of Regulatory Capture", Quarterly Journal of Economics, 106 (4), 1991, pp. 1089-1127.

${ }^{114}$ M. Gal and I. Faibish, "Six Principles for Limiting Government-Facilitated Restraints on Competition" 44 (1) Common Market Law Review, January 2007, pp.9-10.

${ }^{115}$ It is often said that the three-main CRAs have enjoyed numerous years of regulatory protection. In the meantime, CRAs made great efforts to delay the introduction of major changes to the current situation. It is indeed reported that CRAs invest many resources in public relations services and hire lobbyists to undermine legislative amendments. Two million dollars would be spent each year by S\&P and Moody's to pay lobbyists to oppose supervision over the agencies' practices. C. Sanati, "Reed Attacks Lobbying Efforts by Ratings Agencies", Dealbook, 6 April 2010, http://dealbook.nytimes.com/2010/04/06/reed-attacks-lobbying-efforts-byratings-agencies/ ; A. Hallman, "For all the blame, credit raters still count on big banks for support", iWatchNews, 21 April 2011 (http://www.iwatchnews.org/2011/04/21/4286/all-blame-credit-raters-still-countbig-banks-support); Welling@Wedden, "Egad! Egan-Jones", Vol. 8, issue 12, 30 June 30 2006, p. 1 (http://www.egan-jones.com/publicdocs/welling_egad_egan.pdf).
} 


\section{Antitrust Intervention Scenarios}

\section{A. Theoretical and Factual Background}

Up to this point, our analysis has made conceptual and practical arguments in support of antitrust scrutiny in the credit rating industry. But the manifest lack of competition amongst CRAs does not suffice as such to trigger the application of the competition rules. The same is true of the market structure of the credit rating industry. Competition law does not prohibit market concentration as such, be it monopolistic or oligopolistic.

In fact, antitrust law only bites in the presence of an additional behavioral element, i.e. a competition law offense. Like most competition regimes, EU competition law prescribes two types of competition offense. First, Article 101 TFEU prohibits anticompetitive collusion amongst independent undertakings. Second, Article 102 TFEU declares unlawful the abusive conduct of dominant firms.

A prerequisite for antitrust intervention in the credit rating industry is thus the existence of a course of conduct which fulfills the conditions of application of Article 101 or 102 TFEU. It would be beyond the scope of this paper, and extremely difficult, to review the various activities of CRAs that may be tantamount to a competition law offense. ${ }^{116}$ Rather than attempting to draw lines in the water, we thus focus on whether CRAs' recent downgrading suits of sovereign ratings can trigger antitrust liability. ${ }^{117}$

At this stage, a number of additional factual clarifications are necessary. Back in 2007, the CRAs were lambasted for (i) their blind optimism in relation to Subprime securities; and (ii) for the length it took them to warn investors of the dangers associated with such securities. In the aftermath of the Subprime crisis, the pendulum swung. CRAs became extremely pessimistic and anticipative in their ratings. ${ }^{118}$ This change towards a more ex ante approach of ratings magnified the possibility of errors. With this new paradigm, CRAs are now suspected of devising flawed predictions (some talk of "self-fulfilling prophecies"). Within the space of a few weeks, the big three CRAs successively downgraded the sovereign ratings of several European countries (Greece, Ireland, Portugal, Italy) regardless of their lesser

\footnotetext{
${ }^{116}$ After all, most agreements, including cooperation agreements, participation in industry associations, etc. may raise competition issues. The same is true of other types of conduct, such as pricing, investment, marketing and R\&D policies, etc., on which we barely have any information.

117 Our paper will therefore not deal with S\&P's alleged excessive pricing practices in relation to US International Securities Identification Numbers (ISINs) in Europe (which triggered the opening of an investigation by the EU Commission in 2009).

${ }^{118}$ R. Baghai, H. Servaes and A. Tamayo, "Have Rating Agencies Become More Conservative? Implications for Capital Structure and Debt Pricing", June 2011, p. 2
} 
exposure to default than securitized products (e.g. MBS, ABS, etc.). Investors thus sold massive quantities of sovereign bonds, whose "pair" value winded down and whose "yield" skyrocketed. In turn, downgraded countries in need of liquidity have been facing increased financial, economic and social difficulties, as if the initial prediction of the CRAs were correct. The CRAs' catastrophic predictions have triggered saber-rattling among many policy makers, ${ }^{119}$ but also among high-profile economists, etc. ${ }^{120}$

With this background in mind, our main ambition in the following sections is to (i) formulate hypothetical theories of anticompetitive harm under both Articles 101 and 102 TFEU; (ii) gauge their factual plausibility; and (iii) assess their legal vulnerability to competition proceedings. To this end, we review in turn two hypotheses of unlawful, anticompetitive conduct: collusion (B) and abuse of dominance (C). Given the lack of available information on CRAs' market practices, the analysis is necessarily prospective, and thus in no way aspires to be exhaustive.

\section{B. Collusion}

Our first hypothetical scenario draws on the conspiracy theory. ${ }^{121}$ Almost inevitably, the similar timing and content of CRAs' downgrading decisions raises suspicions of collusion. EU Commissioner Reding explicitly alluded to this with the following words: "It cannot be that a cartel of three U.S. firms decides the fate of whole economies and their citizens". ${ }^{122}$

There are several ways in which the "big three" CRAs may have colluded. First, CRAs may have directly conspired to slash sovereign ratings. In the alternative, CRAs may have indirectly colluded, through contacts with common customers or in the context of joint organizations (e.g. trade associations, joint ventures, etc.). Surely, such collusion, if proven, would fall foul of Article 101 TFEU. However, the strategic motives that could prompt CRAs to conspire along those lines remain unclear. After all, collusion on downgrading is unlikely to improve CRAs' profitability. ${ }^{123}$

\footnotetext{
${ }^{119}$ H. Van Rompuy, "Nous vivons une crise non pas de la zone euro mais de l'endettement public", Le Monde, 02.08.2011, talking of "laughable" assessments.

${ }^{120}$ The Nobel Prize economist Christopher Pissarides has explicitly warned against the CRAs' self-fulfilling prophecies. See http://news.pseka.net/index.php?module=article\&id=11642

${ }^{121}$ We leave aside the issue of a conspiracy amongst CRAs that would seek to protect the interest of the US at the expense of the EU, in some sort of economic struggle amongst giant superpowers. The mere fact that S\&P has downgraded US sovereign bonds undermines this somewhat dramaturgic and fictional hypothesis.

${ }_{122} \mathrm{http} / / / \mathrm{ww}$.forexlive.com/blog/2011/07/11/eus-reding-need-to-smash-cartel-of-three-us-rating-agencies/

123 And may even reduce profits, if rated States decide to remove business from them.
} 
A second possible scenario involves larger-scale collusive activities, between CRAs and financial establishments active on other markets (e.g. banks, hedge funds, insurance companies). The CRAs, together with several financial establishments, may have downgraded specific sovereign bonds in order to harm rival financial establishments that are excessively exposed to sovereign debt, i.e. those that purchased sovereign bonds from fiscally-exposed countries or that sold Credit Default Swaps on those bonds. ${ }^{124}$ The CRAs and the colluding banks may also be trying to inflate interests rates on sovereign bonds, with a view to increasing banks' revenues and in turn CRAs' ability to extract higher fees from ratings. ${ }^{125}$

Again, both variants could trigger the applicability of Article 101 TFEU subject to proof of concerted conduct. There is, however, a missing piece in the puzzle: why would CRAs favor certain financial establishments over others? Besides the particular situation of Moody's which is controlled by two investment firms active on the sovereign debt market, ${ }^{126}$ industry data says nothing of this. ${ }^{127}$

This does not mean that the collusion hypothesis should be ruled out. History suggests that the financial sector is not sheltered from collusion. Economic studies have for instance hinted at collusive conduct between issuers and CRAs. ${ }^{128}$ Furthermore, antitrust agencies have themselves uncovered unlawful conspiracies in the financial sector. ${ }^{129}$ Should CAs be ready to investigate risks of collusion, they enjoy sufficient powers to bring the truth to light.

\footnotetext{
${ }^{124}$ C. Gatinois, "Pour les hedge funds, spéculer sur la dette souveraine peut rapporter très gros", Le Monde, 13 July 2011. This strategy would benefit to banks that anticipated the actual crisis and bought Credit Default Swaps as a guarantee against the possible failure of EU States.

${ }^{125}$ Contrary to other debt issuers (e.g. firms, etc.), banks and financial groups that would be interested in increased interests rates have the power to obtain favors from CRAs: "Structured finance accounts for a major share of some rating agencies' total revenues equally important, these amounts are paid by a small number of investment banks that know how to exploit their leverage". J. Coffee, op. cit.,

${ }^{126}$ The principal institutional owners of Moody's are Berkshire Hathaway and Davis Selected Advisers. Berkshire Hathaway is very active on the sovereign debt market. As of 2010, Berkshire owned \$29 billion in fixed income securities, hold $\$ 2$ billion of US government bonds and more than $\$ 10$ billion of foreign government bonds (see Berkshire Hathaway Inc., Annual Report, 2010, p. 74, http://www.berkshirehathaway.com/2010ar/2010ar.pdf). Davis Selected Advisers is an investment management firm which manages several funds. Among those funds, Davis manages a Government Bond Fund. The Fund's strategy is to diversify among different types of government securities, maturity lengths, call provisions, and interest rate coupons. (see http://davisfunds.com/funds/government_fund/).

${ }^{127}$ Beyond the fact that the CRAs have developed symbiotic relationships with banks and other financial institutions that are used to commission credit rating agencies to assess the value of their products.

${ }^{128}$ M. Pagano and P. Volpin, op. cit., p.10, who allude to collusion between issuers and agencies to reveal only coarse information despite product complexity.

${ }^{129}$ For instance, see EU Commission, Press Release, "Commission fines five German banks for fixing the price for the exchange of euro-zone currencies", 11 December 2001, IP/01/1796.
} 


\section{Abuse of Dominance}

The credit rating industry exhibits high levels of concentration. It is thus legitimate to ponder whether the CRAs occupy, individually or jointly, a dominant position (2) and, in turn, whether their ratings conduct is tantamount to an abuse under Article 102 TFEU (3). Prior to this, we look briefly at the issue of market definition, and reach the conservative conclusion that there is a global market for sovereign ratings where the various CRAs compete (1). ${ }^{130}$

\section{Market definition}

Credit rating agencies provide information on the creditworthiness of debt issuers. In its widest acceptation, the relevant market could thus cover all those instruments that disclose information allowing investors to assess credit risk: ${ }^{131}$ financial journals, analyst reports, internal risk-assessment procedures, capital/solvency ratios, any appropriate combination of accounting indicators, etc. ${ }^{132}$

Such a market definition is, however, overly broad. Ratings issued by CRAs exhibit indeed several features that distinguish them from other information channels. First, investors favor CRAs ratings because they enshrine information on the creditworthiness of the debt issuer in the present and in the future, by contrast to static accounting indicators. ${ }^{133}$ Second, portfolio governance and prudential regulation obligations require investors to hold financial products rated by CRAs. ${ }^{134}$ As a result, entities willing to issue bonds are thus obliged to purchase ratings from the CRAs, ${ }^{135}$ regardless of the existence of cheaper risk-assessment instruments.

\footnotetext{
${ }^{130}$ As explained previously, there is a key methodological distinction between sovereign and corporate ratings, which could justify treating the market for sovereign rating services as separate from the market for corporate credit rating services.

${ }^{131}$ It is worth recalling that the relevant market "comprises all those products and/or services which are regarded as interchangeable or substitutable by the consumer". Neither the inaccuracy of the ratings, nor the irrationality of investors who stick with CRAs opinion whatever the cost should alter the market definition. Commission Notice on the definition of relevant market for the purposes of Community competition law, OJ, 9 December 1997, C 372/5, para. 7.

132 European Commission, Public Consultation on Credit Rating Agencies, 5 November 2010 p. 8. (http://ec.europa.eu/internal_market/consultations/docs/2010/cra/cpaper_en.pdf).

133 S. Schaefer, "Stocks Plunge After S\&P Downgrade of U.S. Rating", Forbes, 8 August 2011 http://www.forbes.com/sites/steveschaefer/2011/08/08/market-mauled-after-sp-downgrades-u-s-credit-rating/. ${ }^{134}$ OECD, p.57.

${ }^{135}$ Whatever the accuracy of these predictions - and despite ratings agencies' recent track record of errors market reactions to the announcements made by rating agencies evidence that most investors simply cannot do without CRAs prescriptions. J. Hunt, "Credit rating agencies and the worldwide credit crisis: the limits of reputation, the insufficiency of reform, and a proposal for improvement", Columbia Business Law Review, 2009, 1, pp. 109-209.
} 
Within the market for rating services, a further distinction may be drawn between sovereign and corporate ratings. ${ }^{136}$ First, the customers of corporate and sovereign ratings are different, with on the one hand private sector organizations and, on the other hand, sovereign States able to raise taxes to fulfill their contractual obligations. ${ }^{137}$ Second, the rating of corporate and sovereign bonds involves distinct methodologies. Whilst corporate rating requires the analysis of economic and accounting data only, sovereign rating necessitates a political assessment of a country's willingness to repay its debts. This implies additional working staff with specific expertise on social and political issues. ${ }^{138}$ In turn, this limits supply-side substitution, ${ }^{139}$ given that many CRAs other than the "big three" do not have the brainpower to rate sovereign bonds.

Finally, sovereign ratings are information goods, which can be easily traded across borders. Hence, the market for sovereign ratings is global in scope.

\section{Dominance}

Under conventional Article 102 TFEU principles, the existence of dominant positions in the credit rating industry is not obvious. However, CAs could rely upon less customary, yet applicable, antitrust law doctrines to find the CRAs in positions of single firm (2.1) or collective dominance (2.2).

\subsection{Single Firm Dominance}

At first glance, it seems doubtful that any of the three CRAs individually holds a dominant position. Of course, the market is highly concentrated and characterized by high barriers to entry/expansion. Yet, in principle, there is only one dominant player in a relevant market and this dominant player is necessarily the market leader. ${ }^{140}$ In the present case, the quasi-

\footnotetext{
136 That said, it must be acknowledged that the corporate and sovereign markets share a special relationship. Because of the reputation effects that characterize the rating industry, the market position the three big CRAs were able to achieve on the corporate rating market was leveraged into the market for sovereign ratings. The appetite of investors for ratings from well-known agencies allowed the main CRAs to duplicate their market share on the neighboring market for sovereign ratings. This makes the market for corporate rating a unique entry gate to the market for sovereign rating.

${ }_{137}$ Ibidem, para. 43.

138 "The rating of sovereigns depends more on the art of political economy than on the science of econometrics. It depends on the careful judgement of experienced analysts about the durability of policy and the values of policy-makers as much as on a hard-nosed assessment of the prospects for a nation's export potential". Fitch, Sovereign ratings. Rating methodology, p. 4 http://www.fitchratings.com.bo/UpLoad/methodology.pdf.

${ }^{139}$ Commission Notice on the definition of relevant market, op cit., para. 20.

${ }^{140}$ The market leader must outrank its rivals by some significant margin. See Guidance on the Commission's enforcement priorities in applying Article 82 of the EC Treaty, op. cit., para. 20.
} 
symmetrical market position of Moody's and S\&P rules out any finding of individual dominance.

That said, from both a legal and economic standpoint, there is some sense in arguing that each of the "big three" CRAs - or perhaps only Moody's and S\&P - could exceptionally be deemed to enjoy an individual dominant position. To start with the economics, we already explained that issuers seek to obtain at least two ratings, and sometimes three. ${ }^{141}$ This means that issuers do not view the ratings of the CRAs as substitutes for one another, but rather as complements to one another. Consequently, it could be argued that each CRA operates on a stand-alone, captive market. In turn, this means that each of the three CRAs - or at least Moody's and S\&P - is an "unavoidable trading partner" for issuers. ${ }^{142}$ Put differently, Moody’s, S\&P and Fitch would each enjoy a monopoly position, on their own market.

Turning to the law, CAs and courts could possibly delineate distinct relevant markets for the various CRAs, and find that each of them occupies a dominant position under Article 102 TFEU. Alternatively, and more controversially, CAs could draw inspiration from the Commission's decision in ABG/Oil Companies operating in the Netherlands in which several rival companies operating in the same market were found to enjoy a dominant position relative to their respective customers. ${ }^{143}$ This line of reasoning has, however, never been used in subsequent Article 102 TFEU cases. That said, there is some precedential authority in the case-law to find single firm dominant positions in the credit rating industry.

\subsection{Collective Dominance}

Article 102 TFEU applies to tight oligopolies via the doctrine of "collective dominance". In practice, the Commission has seemed reluctant (if not allergic) to using this doctrine in oligopolistic markets. ${ }^{144}$ However, despite the Commission's reticence, the EU Courts have repeatedly stated that a dominant position may be "held by two or more economic entities legally independent of each other, provided that from an economic point of view they present themselves or act together on a particular market as a collective entity (emphasis added)". ${ }^{145}$ Besides, at the national level, some CAs have built a solid track record in this field. Given the

\footnotetext{
${ }^{141}$ Regulatory frameworks may require issuers to obtain multiple ratings prior to offering bonds on the market.

${ }^{142}$ The concept of "unavoidable trading partner" comes from the seminal judgment of the ECJ in C-85/76, Hoffmann-La Roche v Commission, [1979] E.C.R.461, para 41.

${ }^{143}$ Commission Decision, 77/327/EEC of 19 April 1977, IV/28.841 - ABG/Oil companies operating in the Netherlands, OJ L 117, 09.05.1977, pp. 1-16.

144 Except in very specific circumstances. On this, see N. Petit, Oligopoles, collusion tacite et droit communautaire de la concurrence, Bruylant-LGDJ 2007, Chapitre II.

${ }^{145}$ Ibidem, para. 110.
} 
tight oligopolistic structure of the credit rating industry, it is thus legitimate to examine whether the CRAs hold a collective dominant position.

At its core, the notion of collective dominance covers those oligopolistic markets on which rivals can coordinate their conduct (e.g. price, output, investments, etc.) without entering into an explicit collusive arrangement. Economists refer to this phenomenon with the oxymoron "tacit collusion".

Under Article 102 TFEU, a finding of collective dominance requires: (i) a certain degree of parallel behavior amongst oligopolists (the notion of "collective entity"); and (ii) the satisfaction of the three conditions articulated by the General Court in Laurent Piau v. Commission, i.e.:

"Three cumulative conditions must be met for a finding of collective dominance: first, each member of the dominant oligopoly must have the ability to know how the other members are behaving in order to monitor whether or not they are adopting the common policy; second, the situation of tacit coordination must be sustainable over time, that is to say, there must be an incentive not to depart from the common policy on the market; thirdly, the foreseeable reaction of current and future competitors, as well as of consumers, must not jeopardise the results expected from the common policy."146

Unfortunately, subsequent case-law provides no guidance on the interpretation of those conditions. In previous cases, the Commission and the EU Courts have established collective dominance on the basis of a less sophisticated assessment, which involved the review of a "checklist" of pro-collusive market characteristics or through the proof of "structural links" amongst oligopolists (e.g. agreements, shareholdings, etc.). Moreover, in Impala v. Commission, the Court stressed that:

"in the context of the assessment of the existence of a collective dominant position, although the three conditions [...] which were inferred from a theoretical analysis of the concept of a collective dominant position, are indeed also necessary, they may, however, in the appropriate circumstances, be established indirectly on the basis of what may be a very mixed series of indicia and items of evidence relating to the signs, manifestations and phenomena inherent in the presence of a collective dominant position."

Now, on the facts, the two components of collective dominance are prima facie present. First, parallel behavior is a salient feature of the credit rating industry. ${ }^{147}$ The sovereign debt crisis offers daily illustrations of this, with CRAs repeatedly adjusting their ratings on their

\footnotetext{
${ }^{146}$ CFI (now General Court), 26 January 2005, Laurent Piau v Commission, T-193/02, E.C.R., 2005, p. II-209, para. 111.

${ }^{147}$ R. Cantor and F. Packer, op. cit. , p. 3: As early as 1994, the parallel behavior of the two main agencies was perceivable. In the wake of the financial crisis in Mexico, S\&P had rated Mexico with a positive outlook for upgrade before downgrading its assessment to align it with that of Moody's.
} 
competitors'. In the same vein, several scholarly studies record systematic patterns of "mimetism", "inertia", "herd behavior"148 and "piggybacking effect"149 in the credit rating industry: ${ }^{150}$ successive credit ratings tend to converge after publication; ${ }^{151}$ upgrade probabilities are much higher, and downgrade probabilities are much lower, for a sovereign issuer with a recent upgrade by another agency; ${ }^{152}$ rating changes by a rating agency are also significantly more likely after downgrades than after upgrades by a first rating agency. ${ }^{153}$

Second, the features of the credit ratings sector support a tacit collusion hypothesis. To name only a few of them, the industry exhibits:

a small number of oligopolists;

$>$ similar activities in range, nature and variety; ${ }^{154}$

$>$ identical business models, with the "big three" CRAs operating under the "issuer pays" model;

$>$ similar fees ${ }^{155}$ and similar "list prices"; ${ }^{156}$

${ }^{148}$ Herd behavior can be compounded by managers incentives (reputational issues and sharing the blame in case
of errors). D. Scharfstein and J. Stein, "Herd Behavior and Investments", (1990) Vol 80, N³, American
Economic Review, 465 ,
${ }^{149}$ P. Gomas, Do credit rating agencies piggyback? Evidence from sovereign debt ratings, 19 June 2011 , p. 19 P. Gomas, Do credit rating agencies piggyback? Evidence from sovereign debt ratings, 19 June $2011, \mathrm{p} .19$
(Preliminary draft). What has been described as a "piggybacking effect" has numerous, crucial implications: "First, errors of one agency contaminate the rating of other agencies. Second, if ratings are reported in a categorical scale, piggybacking leads to inertia and herd behaviour. Even if one agency perceives a deterioration of the creditworthiness, it might be reluctant to act if the rivals do not. It will only downgrade if it receives a strong negative signal. On the other hand, once one agency acts, it might generate waves of subsequent adjustments. Third, if agencies are themselves averaging their ratings, investors can get wrong idea about the variance of the signals.

${ }^{150}$ Of course, the CRAs occasionally disagree on ratings, but this is often confined to one or two notches on their finer scale. P. Hill, R. Brooks and R. Faff, "Variations in sovereign credit quality assessments across rating agencies", Journal of Banking \& Finance, 34, 2010, p. 1327. Moreover, divergences seem more frequent for sovereign ratings than for corporate ratings: "The disagreements across agencies represent more than half of all observations, except in the case of the $S \& P / F i t c h$ pair. (...) The high frequency of disagreements across agencies can be explained by rating agencies using varying methodologies, different quantitative/qualitative factors and different weights on these factors in assigning sovereign ratings. Rating agencies may also disagree to a greater extent about speculative grade rated issuers (more opaque issuers with a high degree of instability and poor information quality), which represent $46.4 \%$ of the total number of observations. In addition, agencies may have better knowledge about countries in their "home region", and thus assign favourable ratings for issuers located there." R. Al-Sakka and O. ap Gwilym, "Split sovereign ratings and rating migrations in emerging economies", Emerging Markets Review, 11, 2010, p. 95.

${ }^{151}$ R. Al-Sakka and O. ap Gwilym, "Split sovereign ratings and rating migrations in emerging economies", $o p$. cit., p. 95.

${ }^{152}$ And vice-versa. R. Al-Sakka and O. ap Gwilym, "Leads and lags in sovereign credit ratings", Journal of Banking \& Finance, 34, 2010) 2614-2626: "S\&P tends to demonstrate the least dependence on other agencies, and Moody's tends to be the first mover in upgrades. Rating actions by Japanese agencies tend to lag those of the larger agencies, although there is some evidence that they lead Moody's downgrades".

${ }^{153}$ A. Guttler and M. Wahrenburg, "The adjustment of credit ratings in advance of defaults", Journal of Banking \& Finance, 31, 2007, p. 751.

154 “As of September 2005, S\&P had credit rating opinions outstanding on approximately $\$ 30$ trillion of debt, including 745,000 securities issued by roughly 42,000 obligors in more than 100 countries. 27 Moody's numbers were roughly the same." F. Partnoy, op. cit., p. 66.

${ }^{155}$ Idem, p. 66.

${ }^{156}$ Moody's and S\&P are also said to charge similar fees and to have adopted similar "list prices". The structure of Fitch issuers' fee schedules is similar to that of Moody's and S\&P. "Both Moody's and S\&P have the following "list prices" for the requested ratings: 3.25 basis points on issues up to $\$ 500$ million, with a minimum 
similar cost structures and similar human resources (in size) ${ }^{157}$

$>$ close rating methodologies; ${ }^{158}$

$>$ high market transparency, with the publication of credit ratings, contacts with common customers and through the participation to several professional associations; ${ }^{159}$

Moreover, the three conditions of Laurent Piau v. Commission may well be satisfied. First, CRAs can easily monitor each other's ratings, in light of the high degree of transparency that prevails on the market. Second, CRAs' incentives to follow each other's behavior can be sustained through the threat of price wars or other retaliation mechanisms (poaching of key personnel, e.g. internal analysts), etc. Finally, the likelihood of entry/expansion is presumably low, given the high obstacles that potential/actual rivals must overcome to penetrate the market. The persistence of large profit margins in the credit rating industry corroborates this last proposition. ${ }^{160}$ Overall, the collective dominance/tacit collusion hypothesis is thus plausible.

\section{Abuse}

\subsection{Theoretical Background}

Given that both the individual and collective dominance hypothesis can be sustained, it is now time to turn to the issue of abuse. Under well-settled case law, it is not per se unlawful to hold a dominant position. However, firms occupying a dominant position cannot behave as they see fit on the market. Dominant firms have a "special responsibility not to allow [their] conduct to impair competition on the common market". ${ }^{161}$ In layman's words, certain forms of legitimate business conducts of non-dominant firms are forbidden to dominant firms in view of their likely or actual anticompetitive effects.

fee of \$25,000 and a maximum of \$125,000 (S\&P) or \$130,000 (Moody's); both charge an additional 2 basis points on amounts above $\$ 500$ million ( $\$ \& P$ caps the amount at $\$ 200,000$; it also has a one-time fee of $\$ 25,000$ for first-time issuers). Both offer negotiated rates for frequent issuers and offer quarterly charges on amounts outstanding for issuers of commercial paper. (...) The structure of [Fitch and Duff\&Phelps] issuers' fee schedule is similar to that of Moody's and S\&P; but, as would be expected from firms that are perceived to be more peripheral, their fee levels are lower (2.5 basis points for Fitch IBCA; 2.75 basis points for Duff \& Phelps)". L. White, The credit rating industry: an industrial organization analysis, op. cit., p. 14.

${ }^{157}$ S\&Ps ratings operations are roughly of the same size as Moody's, while Fitch is somewhat smaller. All three companies employ about the same numbers of analysts. L. White, "The Credit Rating Agencies", op. cit., p. 216.

${ }^{158}$ The three main CRAs have similar methodologies for corporate rating. There are more divergences on sovereign rating, though.

159 For instance, the CRAs cooperate within the context of the International Organization of Securities Commissions ("IOSCO"), an association of organisations that regulates the world's securities and futures markets. For more, see http://www.iosco.org/

${ }^{160}$ This despite repeated criticism of stakeholders from all sides.

${ }^{161}$ ECJ, Case 322/81, NV Nederlandsche Banden Industrie Michelin v Commission [1983], E.C.R. p.3461, para. 10. 
The scope of the concept of abuse is open-ended. In essence, however, Article 102 TFEU outlaws conduct which harms the competitive structure of markets through the foreclosure of other firms, be they competitors - first line injury abuses - or economic partners (customers or suppliers active on neighboring markets) - secondary line injury abuses - of the dominant firm. Those abuses are often labeled "exclusionary abuses".

First line injury abuses appear, for instance, in predatory pricing cases, where a dominant firm prices below costs to subdue as efficient rivals. Secondary line injury abuses occur, for instance, in price discrimination cases, where a dominant firm charges different tariffs to its customers, and thereby inflicts on some of them a competitive disadvantage. In recent years, many authors (including the author of this paper) have criticized the lax conditions required in the case-law to prove an unlawful abuse under Article 102 TFEU. Those relatively lax requirements could, however, play to the CAs' advantage, should they be willing to investigate the conduct of CRAs under Article 102 TFEU.

Besides exclusionary abuses, Article 102 TFEU also prohibits so-called "exploitative abuses": conduct whereby a dominant firm exploits its SMP, and harms directly its customers, through excessive prices, output reductions, poor product/service quality, etc. In brief, such abuses cover the several inefficiencies traditionally ascribed by economic theory to monopoly power.

\subsection{Rating Errors}

Ever since their inception, CRAs' have been criticized for misguided decisions, as if errors were an endemic feature of the industry. ${ }^{162}$ In recent times, observers have lambasted CRAs for repeated type I errors (erroneous downgrading or under-rating). Alluding to S\&P's recent downgrading of the US rating - which was fraught with a daft mathematical mistake of approximately $\$ 2$ trillion - ${ }^{163}$ P. Krugmann, a Nobel prize economist, talked of “amateur hour". ${ }^{164}$ Likewise, up until the fall-out of the Subprime crisis, CRAs have been criticized for repeated type II errors (erroneous upgrading or over-rating). In this context, one may thus legitimately question whether such errors are likely to fall foul of Article 102 TFEU.

\footnotetext{
${ }^{162}$ To reverse this argument, CRAs often claim that pursuing them is like blaming the thermometer for the temperature. Some observers have also described CRAs as mere "messengers", and argued that it would make no sense to shoot the messenger. But this is wholly unpersuasive. CRAs ratings do not convey crude information. They embody analysis, value judgment and interpretation, just as a doctor's diagnosis does after taking a patient's temperature. Seen as a diagnosis, credit ratings may thus be flawed.

${ }_{163} \mathrm{See}$ http://www.treasury.gov/connect/blog/Pages/Just-the-Facts-SPs-2-Trillion-Mistake.aspx

${ }^{164}$ See http://krugman.blogs.nytimes.com/2011/08/07/i-heard-it-through-the-baseline/
} 
There are several senses in which CRAs' ratings errors may be akin to unlawful abuses under Article 102 TFEU. First, and to focus only on type I errors, with the mistaken downgrading of selected sovereign ratings, CRAs risk injuring the structure of related financial markets, by pushing sovereign-exposed financial establishments (banks, insurance companies, etc.) towards bankruptcy. ${ }^{165}$ As in secondary line injury cases, this is likely to increase concentration on neighboring markets, weaken competition and harm consumer welfare. Beyond this, the harm caused to competition with the disappearance of specific market players may trigger increased financial instability. ${ }^{166}$

Second, the downgrading of certain countries - despite the drastic economic reforms and austerity measures undertaken in those countries - and the relative immunity of other countries - despite dire economic situations - may be a form of subjective discriminatory conduct, ${ }^{167}$ which inflicts a competitive disadvantage on holders of downgraded bonds.

Finally, rating errors can also be akin to exploitative abuse to the extent that they reflect the structural failure of dominant firms to supply efficient services. Given the absence of competitors, rating errors do not translate into losses in market share, likely to discipline the CRAs. Moreover, dominant CRAs, insulated from competition, need not improve, let alone correct, flawed rating methodologies.

Not unlike our analysis of dominance, we acknowledge that our assessment of abuse is unconventional, and departs from mainstream Article 102 TFEU analysis. We thus recognize that running an Article 102 TFEU case along those lines would probably require a good amount of "political" courage.

This notwithstanding, our interpretation of Article 102 TFEU is based on established competition policy principles. First, it is wholly consistent with the Court's case-law (i) in price discrimination cases, which seeks primarily to avoid distortions of competition on

\footnotetext{
${ }^{165}$ Note that type II errors generate similar concerns, as they induce investors to take excessive risks, and thus weaken their competitive position. The explanation for the rating agencies' conduct can perfectly be framed in the words used by (i) behavioral economists to describe irrational conduct - why hammer Greece and Portugal, and meanwhile maintain the US' AAA? - in markets where players are excessively risk averse; or (ii) conventional economists to describe information imperfections and reputation dynamics (to stay credible, agencies need to be tough on rating).

${ }^{166}$ The contagion dynamics on financial markets are abundantly documented in the scholarship and official reports.

${ }^{167}$ At the end of the day, the rating implies a subjective assessment of the creditworthiness of the issuer. It leaves an important margin of appreciation left to the analyst. This is all the more so when it comes to the rating of sovereign debt, where an assessment of the "political willingness to pay" must be undertaken.
} 
markets where the dominant firm is not active (secondary-line injury); ${ }^{168}$ and (ii) in other types of cases (refusal to deal, rebates, etc.), where dominant firms have been condemned for eliminating trading parties in markets where they were not active. ${ }^{169}$ For instance, in British Airways ("BA"), the General Court objected to the fact that the various travel agents that purchased tickets to BA received different rebates. The Court held that such a discriminatory rebate scheme, ${ }^{170}$ could distort competition on the downstream market for air travel agency services and was thus abusive. ${ }^{171}$ Albeit implicitly, the Commission confirmed this in its Discussion Paper on Article 102 TFEU. It suggested that abuse concerns could arise if the elimination of a market player led to collusion in the secondary market, or if the eliminated market player was a key source of rivalry (e.g. a maverick player). ${ }^{172}$

Second, it tallies with the Commission's goals under the State aid rules, where bailouts to failing firms are (i) generally authorized out of concerns of increased oligopolistic concentration; ${ }^{173}$ and (ii) specifically cleared in the banking industry, for fear of increased financial instability and risks of contagion. ${ }^{174}$

Finally, Regulation 1/2003 entitles national CAs to adopt decisions that go beyond customary Article 102 TFEU principles. ${ }^{175}$ National CAs, could thus draw inspiration from the above to run novel, creative theories of harm under domestic abuse of dominance law.

\subsection{Extortionate Ratings}

CRAs occasionally issue unsolicited ratings. ${ }^{176}$ Unsolicited ratings are credit ratings not initiated at the request (and with the cooperation) of the relevant issuer. ${ }^{177}$ In the aftermath of

\footnotetext{
${ }^{168}$ D. Geradin and N. Petit, "Price Discrimination under EC Competition Law - Another Doctrine in Search of Limiting Principles?” (2006) 2(3) Journal of Competition Law and Economics, 479.

169 See, for instance, ECJ, Case 27/76, United Brands Company and United Brands Continentaal BV $v$. Commission, [1978] ECR 207.

${ }^{170}$ GC (previously CFI), British Airways plc v Commission, 17 December 2003, T-219/99, ECR, 2003, p. II05917, para. 233-240.

${ }^{171}$ Ibidem. By remunerating at different levels services that were nevertheless identical the rebates schemes distorted the level of remuneration which the travel agents received. "Being dependent on the financial resources of each agent, that ability of agents to compete in supplying air travel agency services to travellers and to stimulate the demand of airlines for such services was naturally affected by the discriminatory conditions of remuneration inherent in BA's performance reward schemes". Hence, BA's rebates schemes were held to be an abuse of a dominant position, "in that they produced discriminatory effects within the network of travel agents established in the United Kingdom, thereby inflicting on some of them a competitive disadvantage".

${ }^{172}$ See DG Competition discussion paper on the application of Article 82 of the Treaty to exclusionary abuse, Brussels, December 2005, para. 222-223.

${ }^{173}$ Communication from the Commission - Community guidelines on State aid for rescuing and restructuring firms in difficulty, OJ $244,01.10 .2004$, pp.2-17, para. 31.

${ }^{174}$ T. Beck, D. Coyle, M. Dewatripont, X. Freixas and P. Seabright, "Bailing out the Banks: Reconciling Stability and Competition - An analysis of state-supported schemes for financial institutions", CEPR 2010.

${ }^{175}$ Article 3 of Regulation 1/2003, supra.
} 
the Subprime crisis, regulators have encouraged unsolicited ratings in order to mitigate the nefarious effects "issuer pays" conflict of interest. In addition, regulators have entitled nonofficially recognized CRAs to issue such ratings, in a bid to foster transparency, information availability and differentiation on the market. A number of sovereign ratings are unsolicited, but not all of them. ${ }^{178}$

In practice, unsolicited ratings are often below solicited ratings. Observers have thus voiced concerns that CRAs may deliberately issue negative unsolicited ratings in order to push issuers to solicit ratings. ${ }^{179}$ As explained by Partnoy "the agency threatens the issuer with unfavorable ratings to obtain fees now". ${ }^{180}$ The problem here is that someone is forced to purchase a service he does not want, and has to divert resources away from alternative, more valuable, uses. ${ }^{181} \mathrm{We}$ refer to this as extortionate ratings.

When practiced by dominant CRAs, extortionate ratings may have two types of anticompetitive effect. First, the influx of new customers caused by negative unsolicited ratings increases the size of the CRAs' (individual/collective) dominant position, and in turn the magnitude of the various inefficiencies arising from its (their) SMP. ${ }^{182}$ Second, dominant CRAs reduce the contestable share of the market that can be served by prospective new entrants, by locking-in customers that were not previously tied in by contractual commitments. In so doing, the dominant CRAs protect their (individual/collective) dominant position. $^{183}$

On close examination, the case-law of the EU courts to date provides no precedent in relation to such types of abuse. Forced purchasing has only been prohibited to the extent that it was

\footnotetext{
${ }^{176}$ See http://ftalphaville.ft.com/blog/2010/07/28/300116/the-unpredictability-of-the-unsolicited-rating/

177 Regulation No 1060/2009 of the European Parliament and of the Council of 16 September 2009 on credit rating agencies, OJ L 302, 17.11.2009, p. 1-31, recital 21: "An unsolicited credit rating, namely a credit rating not initiated at the request of the issuer or rated entity, should be clearly identified as such and should be distinguished from solicited credit ratings by appropriate means".

${ }^{178}$ See http://ftalphaville.ft.com/blog/2011/02/17/491736/gratuitous-sovereign-aaa/

${ }^{179}$ W. Poon, “Are unsolicited credit ratings biased downward?”, Journal of Banking \& Finance, Vol. 27, Issue 4, April 2003, pp. 593-614; W. POON and M/ FIRTH, “Are Unsolicited Credit Ratings Lower? International Evidence From Bank Ratings”, Journal of Business Finance \& Accounting, Vol. 32, Iss. 9-10, November 2005, pp.1741-1771.

${ }^{180}$ F. Partnoy, op. cit., p. 72.

181 This is a source of allocative inefficiency.

182 One could however argue that this is likely to generate productive efficiency. With an increased customer base, CRAs will achieve economies of scale and reduce their production costs.

${ }^{183}$ Interestingly, CRAs often claim that unsolicited ratings mainly serve as a signaling device, to prove that they even have expertise in markets in which they have no significant presence. The publication of unsolicited ratings is used here as a marketing instrument. C. Bannier, P. Behr and A. Gäuttler, "Why are unsolicited ratings lower than solicited ratings? A theoretical and empirical assessment", 28 April 2007, p. 2 (http://www.finance.uni-frankfurt.de/master/brown/181.pdf).
} 
the result of a tying strategy under Article 102 (d) TFEU (where the sale of good $\mathrm{X}$ is conditioned on the purchase of good Y). That said, extortionate ratings may be sanctioned for its exploitative effects, in the spirit of the prohibition of "unfair purchase conditions" under Article 102 (a) TFEU. In addition, extortionate ratings may also constitute a new breed of exclusionary abuse under Article 102 (b) TFEU. If dominant firms can be condemned when they attract new customers through low prices (in abusive rebates and predatory pricing cases), it seems justified to sanction them when they reach the same result through mischievous practices. ${ }^{184}$

\subsection{Other Possible Abuses}

In addition to the ratings-related abuses discussed above, a wide array of other commercial practices of the CRAs' may fall within the purview of Article 102 TFEU: exclusivity obligations, long-term contracts, tying/bundling of services, unfair contract terms, loyalty discounts, etc. Absent further information on CRAs' commercial practices, it is beyond the scope of this paper to explore their compatibility with Article 102 TFEU. But an antitrust investigation could possibly shed light on a number of abusive practices which, to date, have not yet surfaced on the radar screen of CAs.

\section{Competition Advocacy}

Short of a competition infringement - and of enforcement initiatives by CAs - it would still be perfectly legitimate for CAs to undertake a competitive assessment of the credit rating sector. ${ }^{185}$ Indeed, competition agencies are well placed to ascertain the causes, consequences and solutions to "competition problems" in specific industries. ${ }^{186}$ They should in turn use they actually often do - their expertise to advocate before policy makers regulatory reforms that foster competition. The former Director General of DG COMP, Philip Lowe, summarized this in saying: "One thing the crisis has served to highlight is the importance of good regulation and the need to expand our sphere of influence from beyond the narrow

\footnotetext{
${ }^{184}$ The case-law on sham action (Astra Zeneca) and on other deceptive practices (Rambus) seems to support this contention.

${ }^{185}$ See, in the same sense, House of Lords, European Union Committee, 21st Report of Session 2010-12, Sovereign Credit Ratings: Shooting the Messenger?, 21 July 2011, para. 100: "There is a compelling argument for a thorough competition inquiry into the structure and regulation of the credit rating industry. This inquiry should consider the full range of ideas proposed to increase competition in the sector".

186 They boast expert staff and, in contrast to industry regulators, are less prone to capture. The concept of "competition problem", as opposed to competition infringement, was used by P. Lowe, in a speech available at http://ec.europa.eu/competition/speeches/text/sp2009_15_en.pdf
} 
confines of our specialist field". ${ }^{187}$ In the EU, Article 17 of Regulation 1/2003 offers a legal basis to this end. ${ }^{188}$ In the past, DG COMP relied on this provision to make proposals for regulatory reforms in a number of areas (telecommunications, electricity, gas, pharmaceuticals, etc.). ${ }^{189}$

\section{V. $\quad$ Remedies}

\section{A. $\quad$ Background}

Beyond the prohibition of unlawful agreements and abuses, CAs can impose on parties - or negotiate with them - behavioral and structural measures. Importantly, those remedies must be competition-related, i.e. they must correct and eliminate infringements of the competition rules.

Besides the legal principles of proportionality and effectiveness, imagination seems to be the sole limitation on admissible remedies in competition law. In the section that follows, we thus try to explore a few possible remedies, drawing inspiration from the wealth of policy proposals that have come to light in recent weeks. Again, the analysis here is wholly prospective, and thus does not intend to be exhaustive.

\section{B. Remedies creating or assisting "competitive forces" External to the Oligopoly}

Recent policy proposals call for the creation of one (or more) new CRA(s), to assuage concerns that the "big three" CRAs' flawed appraisals are never disputed by external opinions (or sanctioned by customers).

The decision-making practice of CAs contains many examples of remedies seeking to destabilise a tight oligopoly, through the creation of new "competitive forces". In the credit rating industry, such remedies could be instrumental in helping potential entrants gain a foothold in the market place. ${ }^{190}$ Amongst possible examples, one can think of compulsory

\footnotetext{
${ }^{187}$ Idem, p.9.

188 Article 17 of Regulation 1/2003, supra: "Where the trend of trade between Member States, the rigidity of prices or other circumstances suggest that competition may be restricted or distorted within the common market, the Commission may conduct its inquiry into a particular sector of the economy or into a particular type of agreements across various sectors. In the course of that inquiry, the Commission may request the undertakings or associations of undertakings concerned to supply the information necessary for giving effect to Articles 81 and 82 of the Treaty and may carry out any inspections necessary for that purpose".

${ }^{189}$ For an overview, see N. Petit and C. Lousberg, "Enquêtes sectorielles : Complément ou substitut de l'action des autorités de concurrence ? Le «Couteau suisse » du droit européen de la concurrence ?" Concurrences, $\mathrm{N}^{\circ} 2$ 2010, pp. 19-28.

${ }^{190}$ Interestingly, the benefit of those remedies could be extended to investors, so they can establish their own, internal rating capacities. They could also benefit public CRAs', if it is ever decided, as proposed by several policy makers, to create such organs. We observe here that a public rating agency would probably lack independence and credibility insofar as the rating of sovereign bonds is concerned.
} 
trademark licenses on CRAs, in order to help potential entrants overcome reputational disadvantages. In the same vein, CRAs may be ordered to disclose information on ratings procedures and methodology, so as to assist potential entrants overcome informational disadvantages. Likewise, CRAs may be required to terminate existing contractual relationships with a number of issuers, with a view to creating market opportunities for new entrants. Finally, and as a last resort remedy, CAs could request the main CRAs to sell some of their assets to potential competitors, through a divestiture. ${ }^{191}$

Of course, the corrective virtue of competition remedies goes hand in hand with several drawbacks. First, most of those remedies exhibit endogenous shortcomings. Trademark licenses convey risks of collusion amongst licensors and licensees. Compulsory disclosure remedies may deter innovation in the setting of new assessment methodologies. ${ }^{192}$ Divestitures entail possible productive inefficiencies (loss of economies of scale in particular). ${ }^{193}$

Second, those remedies have exogenous limitations. First, they are contingent on the existence of entrepreneurs, ready to enter the market. Second, as long as the new entrants are not officially recognized as rating institutions in national regulatory frameworks, the impact of their entry on the market will remain limited.

\section{Remedies seeking to reduce Risks of Ratings Errors}

As seen above, there is a widespread concern that ratings errors are pervasive. Rating errors include type I errors (unjustified downgrading or under grading), type II errors (unjustified upgrading or over grading) and ratings discrimination. On a cursory analysis, it can be argued that rating errors give rise to a competition problem, because they translate into anticompetitive effects on adjacent markets where financial establishments operate. ${ }^{194}$ To take the words of economists, ratings errors generate negative externalities on financial establishments exposed to sovereign debt.

\footnotetext{
${ }^{191}$ Structural remedies of this kind are not uncommon in competition law. See United States v. AT\&T, 552 F.Supp. 131 (DDC 1982). In EU competition law, such remedies can only be adopted upon proof that there is no behavioral remedy of equal effectiveness.

${ }^{192}$ L. White, "The Credit Rating Agencies", op. cit., p. 223. There is, however, a shortcoming here: in the longterm, such approach could deter innovation in the setting of new assessment methodologies.

${ }^{193}$ R. Crandall, The Failure of Structural Remedies in Sherman Act Monopolization Cases, AEI-Brookings Joint Center Working Paper No. 01-05, 2001, 89.

${ }^{194}$ Insofar as type II errors are concerned, the risk is that holders of unduly upgraded securities are incentivized to take excessive risks.
} 
Several remedies can be envisioned to reduce risks of rating errors. Whilst some of them are clearly beyond the reach of competition rules (stricter civil and criminal liability rules in cases of errors, publication of a "ranking" of CRAs, etc.), others such as the transition from the "issuer pays" model to the "investor pays" model; or the adoption of "shaming" commitments in case of ratings errors, could arguably be adopted pursuant to them.

Remedies may also be ordered to mitigate the anticompetitive effects of ratings errors. In this variant, CRAs could be requested to use larger ratings scales, which limit the magnitude of downgrades and send less radical signals to investors. CRAs could also be subject to downgrading "floors" or "shutdown obligations", when a country benefits from financial rescue measures under an international programme. ${ }^{195}$

\section{Remedies seeking to eliminate Coordination within the Oligopoly}

Convergence is a prominent feature of the credit rating industry. To undermine this, CAs could seek to generally eradicate collaborative opportunities between incumbent CRAs, through the severance of commercial and structural links (contracts, cross-shareholdings, interlocking directorates, participation in trade associations, etc.). Such links are often deemed to facilitate explicit or tacit collusion.

Besides this, more targeted - yet heavy-handed - remedies could be envisioned. For instance, CAs could ban CRAs from publishing ratings. ${ }^{196}$ In this model, CRAs would send their ratings to a designated institution (the $\mathrm{CA}$ itself or a trustee), whose role would be to publish the ratings of the various CRAs simultaneously. The simultaneous publication of ratings would prevent CRAs from relying on the assessment made by their rivals to frame their own results.

\section{Conclusion}

The recent concern for media pluralism in the United Kingdom following the BSKYB debacle brings a welcome reminder that when it comes to information, there is some strength in numbers. Arguably, the same applies to the credit rating industry where, for too long, ratings are assigned by three entrenched players whose mistakes remain entirely unpunished.

\footnotetext{
195 An idea initially suggested by France's former finance minister, Ms. C. Lagarde. See Nikki Tait, EU eyes more stringent rating requirements, Financial Times, 11.07.2011, available at http://www.ft.com/intl/cms/s/0/63e97e8e-abc2-11e0-8a64-00144feabdc0.html\#axzz1 V6ZWgqrI.

${ }^{196}$ This remedy draws analogy with the proposed creation of a centralized clearing platform for CRAs, proposed by Matthew Richardson and Lawrence White, The Rating Agencies: Is Regulation the Answer? , http://whitepapers.stern.nyu.edu/summaries/ch03.html
} 
There are both conceptual and practical arguments in support of opening a general antitrust investigation into the credit rating industry (at least to complement current regulatory debates). In the past, antitrust inquiries have been opened in sectors where competition concerns were much less glaring. ${ }^{197}$ Furthermore, the Commission is currently investigating S\&P in relation to the licensing of US International Securities Identification Numbers. ${ }^{198}$ In light of all this, the decision to open a sector-wide competition investigation - which lies in the hands of CAs' high-ranking officials - thus seems to rest on one single parameter: political courage... ${ }^{199}$

\footnotetext{
${ }^{197}$ For instance, in the pharmaceutical and retail banking industries, where many problems arise from regulatory frameworks and consumer biases. See N. Petit and C. Lousberg, supra.

${ }^{198}$ Commission confirms sending of Statement of Objections to Standard \& Poor's', Press Release, MEMO/09/508, 19 November 2009.

${ }^{199}$ With mounting pressure from policy makers, legislators and the public opinion, it may just be a matter of time before a CA in the EU or the US decides to open such an investigation. However, some may point out that tougher enforcement initiatives against CRAs might lead to further downgrading in retaliation. See, on this, J. Manns, The Revenge of the Rating Agencies, The New York Times, 09.08.11. However, this justifies launching an investigation against them all the more, to curb their immense power and influence.
} 